\title{
PHYTOPLANKTON COMMUNITY STRUCTURE IN AN INTEGRATED MULTI-TROPHIC AQUACULTURE SYSTEM REVEALED BY MORPHOLOGICAL ANALYSIS AND HIGH- THROUGHPUT SEQUENCING
}

\author{
QIAO, L. ${ }^{1,2,3}-$ CHANG, Z. $.^{2,3}-$ LI, J. ${ }^{2,3 *}-$ CHEN, Z. ${ }^{2,3}$ \\ ${ }^{1}$ Key Laboratory of Sustainable Utilization of Technology Research for Fishery Resource of \\ Zhejiang Province, Marine Fishery Institute of Zhejiang Province, Zhoushan 316012, China \\ ${ }^{2}$ Key Laboratory of Sustainable Development of Marine Fisheries, Ministry of Agriculture and \\ Rural Affairs; Yellow Sea Fisheries Research Institute, Chinese Academy of Fishery Sciences, \\ Qingdao 266071, China \\ ${ }^{3}$ Laboratory for Marine Fisheries and Food Production Processes, Pilot National Laboratory \\ for Marine Sciences and Technology, Qingdao 266071, China \\ *Corresponding author \\ e-mail: lijian@ysfri.ac.cn; phone: +86-532-8583-0183
}

(Received $11^{\text {th }}$ Nov 2019; accepted $30^{\text {th }}$ Jan 2020)

\begin{abstract}
With increasing concern over the negative environmental impact of mariculture, integrated multi-trophic aquaculture (IMTA) has received extensive attention in recent years. To comprehensively assess the phytoplankton community structure in the late culture stage of a typical pond IMTA system, both morphological analysis and high-throughput sequencing method were used in the present study. 9 phyla of phytoplankton were identified by using the two methods, and the Bacillariophyta, Cyanophyta and Euglenophyta were the most dominant. The dominant phytoplankton of the IMTA pond system in which clams were reared in a separate pond has changed from cyanophytes to diatoms from September to October, and it has changed from diatoms and cyanophytes to euglenophytes, haptophytes and green algae in the IMTA pond with shrimp, crab and clam together. Results of direct gradient analysis revealed that the phytoplankton community structure seemed to be linked with the variables of temperature, salinity, $\mathrm{pH}$, dissolved inorganic nitrogen (DIN) and dissolved silica (DSi) concentrations, DIN/dissolved inorganic phosphorus (DIP), DSi/DIN and DSi/DIP. The relationship between phytoplankton community and Vibrio abundance indicated that diatoms and chlorophytes might inhibit the proliferation of Vibrio, while cyanophytes bloom might be beneficial to the Vibrio growth.
\end{abstract}

Keywords: phytoplankton, water quality, Vibrio, mariculture, aquaculture models

\section{Introduction}

As one of the most important seafood production practices worldwide, aquaculture is facing serious environmental challenges due to the detrimental impacts of intensive farming methods (Sladonja, 2011). Integrated multi-trophic aquaculture (IMTA) has been known as an ecologically well-balanced aquaculture practice, in which co-cultures of species at various trophic levels are able to promote the recycling of aquaculture wastes as a food resource (Chopin et al., 2008). In this system, fish or shrimp are cultured in combination with other extractive species, such as filtering clam, which can prevent additional nutrient inflow into the surrounding environment, and they are desirable products with high market value as well (Troell et al., 2009). IMTA has been practiced for several decades in China, initially through land-based operations which later expanded to marine systems (Wartenberg et al., 2017). However, the IMTA is still 
heavily relying on traditional and inefficient methods, and further study on developing engineered IMTA systems that are well adapted to a variety of species and environmental circumstances are needed.

Phytoplankton plays a very important role in aquaculture ecosystems. They are useful in maintaining water quality by uptake of nutrients during photosynthesis (Harrison et al., 2005), and serve as a direct or indirect food source for cultured organisms (Pulz and Gross, 2004; Martins et al., 2016). In addition, beneficial phytoplankton might inhibit the growth of pathogenic bacteria. The Vibrio is ubiquitous in the marine and estuarine environments (Pruzzo et al., 2005a). The genus includes some species (e.g. Vibrio parahaemolyticus, V. harveyi, V. anguillaris, V. alginolyticus, $V$. vulnificus) that is pathogenic to both invertebrates and vertebrates, such as corals, clam, shrimp and fish (Pruzzo et al., 2005b). Studies showed that some phytoplankton, such as diatoms and green algae can effectively inhibit the multiplication of Vibrio (LioPo et al., 2005), while some phytoplankton (such as cyanophytes) might facilitate the proliferation of Vibrio in their natural environment (Eiler et al., 2007). The establishment of a healthy aquaculture environment requires a balance of algae that is beneficial to its organisms. The succession of dominant species often dominates the trend of algal facies balance, which affects the quality of water environment and the healthy development of aquaculture (Xu et al., 2015). So, monitoring and assessing the phytoplankton community structure and dominant species succession are vital in managing aquaculture systems.

In this study, the phytoplankton community structure and dominant species succession in the late stage of a typical pond IMTA system were assessed using traditional morphological analysis and high-throughput sequencing together, and its relationship with the water quality parameters were analyzed as well. Our primary objectives were to (i) clarify the phytoplankton community structure of pond IMTA system using morphological analysis and high-throughput sequencing; (ii) investigate the relationship between phytoplankton community and water quality parameters; and (iii) explore the effect of the aquaculture model on water quality and phytoplankton community.

\section{Materials and methods}

\section{IMTA systems and sample collection}

This study was performed in Rizhao Kaihang Aquatic Products Co., Ltd., located in Shandong Province in eastern China $\left(35^{\circ} 19^{\prime} 8^{\prime \prime} \mathrm{N} ; 119^{\circ} 24^{\prime} 40^{\prime \prime} \mathrm{E}\right)$ in September and October in 2018. Two pond IMTA models were selected in this study, One model (aquaculture model I) consists of a culture pond (pond 1), where Fenneropenaeus chinensis were co-cultured with Portunus trituberculatus and tilapia (Oreochromis niloticus) together, and a biological purification pond (pond 3) with clam Meretrix meretrix stocked was connected to pond 1 through a recirculating pipeline system (Fig. $1)$. The other model (aquaculture model II) is polyculture of shrimp ( $F$. chinensis), crab (P. trituberculatus) and clam (Mercenaria mercenaria) together in the same pond as shown in pond 5 and 6 in Fig. 1. During the study period, Fresh baits and commercial feeds containing $38 \%$ of crude protein (Tongwei Co., Ltd., Lianyungang) were provided in pond 1, 5 and 6 . Feed amount was adjusted daily according to the estimated aquatic animals consumption, mortality rate and leftover feed. No supplemental feed was provided in pond 3 during the study period. 

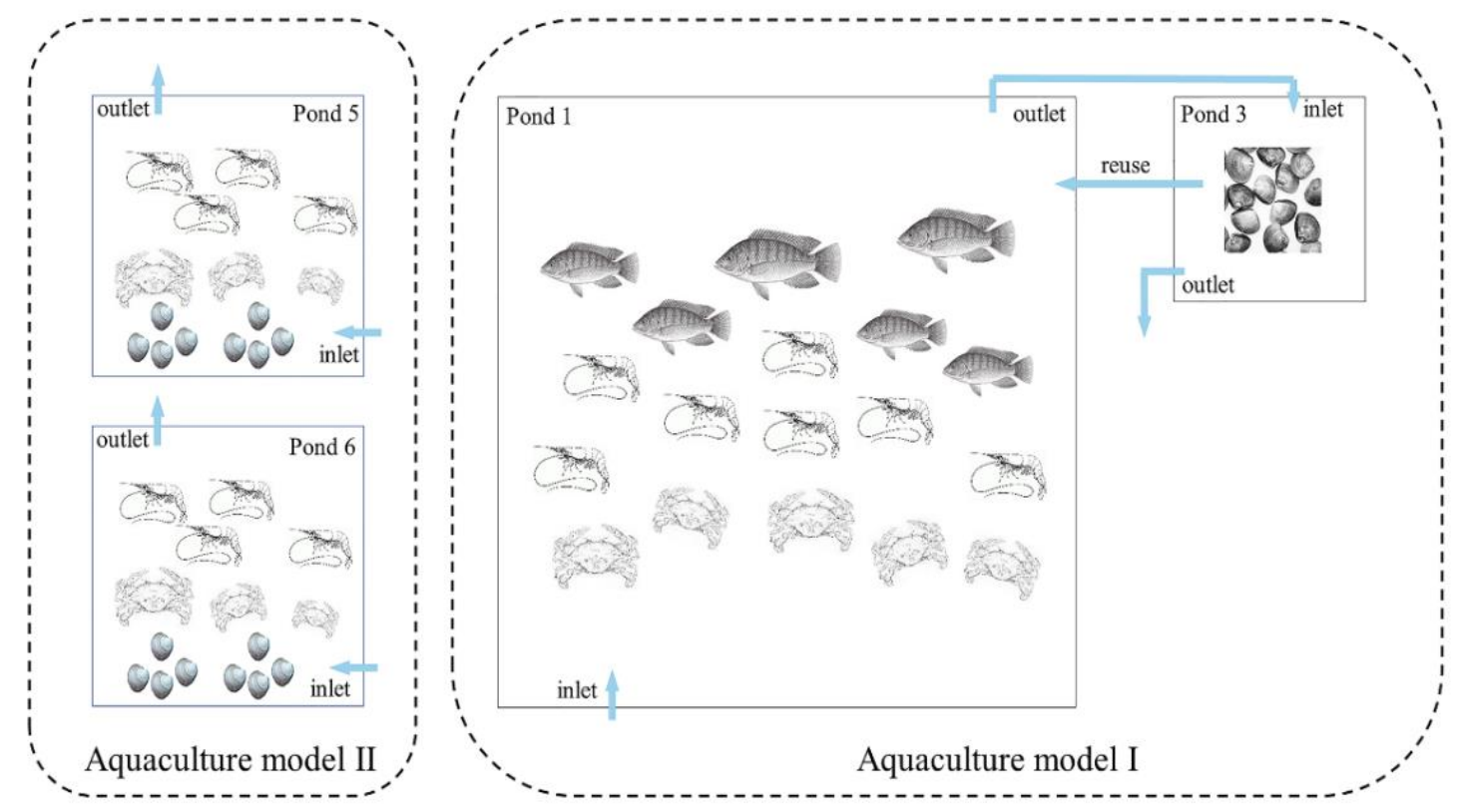

Figure 1. Schematic illustration of the simplified plan of IMTA system. Aquaculture model I consists of pond 1 where $F$. chinensis were co-cultured with P. trituberculatus and $O$. niloticus together and pond 3 where M. meretrix stocked. Aquaculture model II consists of pond 5 and 6 where F. chinensis, P. trituberculatus and M. mercenaria cultured together in the same pond

Samplings were conducted on September 7 and October 17, 2018. The sampling methods referred to Qiao et al. (2019). Water temperature, sanity, dissolved oxygen (DO) and $\mathrm{pH}$ in each pond were recorded in situ using a YSI Model Handheld Instrument (YSI Incorporated, Yellow Springs, Ohio, USA). 1 L of water were sampled from the center and four corners (including the water inlet and the water outlet) of the culture pond, respectively. $5 \mathrm{~L}$ of water samples were well mixed and then prefiltered through a sieve with a pore size of $200 \mu \mathrm{m}$ to remove large suspended particles, microzooplankton, and other large cells. Then, $1 \mathrm{~L}$ of filtrate fixed with $5 \mathrm{~mL}$ of Lugol's solution for phytoplankton identification and counting, $500 \mathrm{~mL}$ of filtrate was further filtered with $0.22 \mu \mathrm{m}$ Millipore membrane to collect the phytoplankton for DNA analysis, and $500 \mathrm{~mL}$ of filtrate was further filtered with $0.45 \mu \mathrm{m}$ membranes to measure the ammonium $\left(\mathrm{NH}_{4}{ }^{+}\right)$, nitrate $\left(\mathrm{NO}_{3}{ }^{-}\right)$, nitrite $\left(\mathrm{NO}_{2}^{-}\right)$, phosphate (dissolved inorganic phosphorus, DIP), silicate (dissolved silica, DSi), dissolved total nitrogen (DTN) and dissolved total phosphorus (DTP) contents.

\section{Analysis of water quality parameters}

Concentrations of $\mathrm{NH}_{4}^{+}, \mathrm{NO}_{3}^{-}, \mathrm{NO}_{2}^{-}, \mathrm{DIP}$, and DSi were measured using a QuAAtro nutrient auto analyzer (Seal Analytical Ltd., Germany) (Parsons et al., 1984). DTN and DTP were determined with alkaline persulfate digestion (SAC, 2007) and evaluated using a QuAAtro nutrient auto analyzer (Seal Analytical Ltd., Germany). The dissolved inorganic nitrogen (DIN) concentration was the sum of $\mathrm{NH}_{4}{ }^{+}, \mathrm{NO}_{3}{ }^{-}$and $\mathrm{NO}_{2}{ }^{-}$ concentrations. The dissolved organic nitrogen (DON) and dissolved organic phosphorus (DOP) values were calculated as the difference between DTN and DIN and between DTP and DIP, respectively. 


\section{Quantitative analysis of Vibrio}

To quantify patterns in the whole Vibrio community, the primer pair Vib1-f (5'GGCGTAAAGCGCATGCAGGT-3') and Vib2-r (5'GAAATTCTACCCCCCTCTACAG-3') (Thompson et al., 2004; Vezzulli et al., 2012) were used to amplify 16S rRNA genes specific to the Vibrio genus (114 bp). All qPCR assays were carried out in triplicate using an ABI PRISM ${ }^{\circledR 7500 ~ S e q u e n c e ~ D e t e c t i o n ~}$ System (Applied Biosystems, USA) with the SYBR Green method to determine the copy concentration of Vibrio. The abundance of Vibrio was expressed as number of cells per liter (cells/L), which was calculated by the average $16 \mathrm{~S}$ rDNA copy number in vibrios (Acinas et al., 2004; Vezzulli et al., 2012).

\section{Morphological analysis of phytoplankton}

The water samples for morphological analysis of phytoplankton were preserved with $0.5 \%$ Lugol's solution. Each sample was concentrated to $50 \mathrm{~mL}$, and then stored in darkness at $4{ }^{\circ} \mathrm{C}$ until analysis. Phytoplankton species were identified and cell numbers were counted using a phytoplankton enumeration chamber under an inverted microscope (Olympus CKX41, Olympus Corporation, Tokyo, Japan).

\section{High-throughput sequencing of phytoplankton and bioinformatic analysis}

The total genomic DNA was extracted from all samples using the FastDNA spin kit for soil (MP Biomedicals, OH, USA), following the manufacturer's instructions. DNA quality and concentration were measured by gel electrophoresis and a Nanodrop spectrophotometer (NanoDrop Technologies, Wilmington, DE, USA), respectively. PCR was performed with the 23S rDNA gene primer pair p23SrV_fl (5'-GGA CAG AAA GAC CCT ATG AA-3') and p23SrV_r1 (5'-TCA GCC TGT TAT CCC TAG AG-3') (Sherwood and Presting, 2007). The PCR products were extracted from a 2\% agarose gel and further purified using the AxyPrepDNA Gel Extraction Kit (Axygen Biosciences, USA) referring to the manufacturer's instruction, and quantified using QuantiFluor ${ }^{\mathrm{TM}_{-} \mathrm{ST}}$ (Promega, USA). Purified amplicons were pooled in equimolar and paired-end reads (PE300) on an Illumina MiSeq platform (Illumina, San Diego, USA) referring to the standard protocols by Majorbio Bio-Pharm Technology Co. Ltd (Shanghai, China). Sequence data can be retrieved from GenBank under accession number SRP185765 and SRP185766.

Sequences from the Illumina MiSeq platform were processed using the QIIME (version 1.91, http://qiime.org/, Caporaso et al., 2010) software package. Raw fastq files were demultiplexed, quality-filtered by Trimmomatic and merged by FLASH (version 1.2.11, https://ccb.jhu.edu/software/FLASH/index.shtml, Magoc and Salzberg, 2011). Operational taxonomic units (OTUs) were clustered with $97 \%$ similarity cutoff using UPARSE (version 7.1, http://drive5.com/uparse, Edgar, 2013). The chimeric sequences were identified and removed using UCHIME (version 7, http://www.drive5.com/uchime, Edgar et al., 2011). The taxonomic assignment was determined for the representative sequence of each OTU using the Basic Local Alignment Search Tool (BLAST) in the NCBI database (http://www.ncbi.nlm.nih.gov). Following the exclusion of bacteria (all non-cyanobacteria) and unclassified sequences, phytoplankton sequences were selected for analysis of community structure and diversity based on the taxonomic information. 


\section{Phytoplankton community analysis}

Dominant species was defined as its dominance $>10 \%$. Phytoplankton community diversity was evaluated using the Shannon-Wiener diversity index.

Phytoplankton dominance:

$$
\mathrm{Y}=\frac{n_{i}}{N} \times f_{i}
$$

In Equation 1, $n_{i}$ is the species cell abundance, $N$ is the total cell abundance, and $f_{i}$ is the frequency of the occurrence of the species in a pond.

Shannon-Wiener diversity index:

$$
\mathrm{H}=-\sum_{i=1}^{S} P_{i} \ln P_{i}
$$

In Equation 2, S is the total number of species or OTUs, and $P_{i}$ is the relative abundance of species $i$ or OTUi.

Correlations between phytoplankton community and water quality parameters were determined through direct gradient analysis using Canoco for Windows (version 4.5, Braak and Smilauer, 2002).

\section{Results}

\section{Water quality parameters and abundance of Vibrio}

The Water quality parameters and the abundance of Vibrio in the aquaculture waters of IMTA system are summarized in Table 1. During the whole study period, the surface seawater temperature declined from $26.32^{\circ} \mathrm{C}$ to $18.24^{\circ} \mathrm{C}$, the average salinity, DO and $\mathrm{pH}$ increased from 23.01 to $26.01 \mathrm{~g} / \mathrm{L}, 4.85$ to $6.84 \mathrm{mg} / \mathrm{L}$ and 8.19 to 8.70 , respectively, while the concentration of $\mathrm{NH}_{4}{ }^{+}, \mathrm{NO}_{3}^{-}, \mathrm{NO}_{2}{ }^{-}, \mathrm{DIN}, \mathrm{DON}, \mathrm{DIP}$ and DSi, were decreased. The average abundance of Vibrio in September was three orders higher than that in October (Table 1). The analysis of variance showed that there were significant differences in water quality between different aquaculture models $(p<0.05)$. The average concentrations of $\mathrm{NH}_{4}^{+}, \mathrm{NO}_{3}{ }^{-}, \mathrm{NO}_{2}^{-}, \mathrm{DIN}, \mathrm{DON}, \mathrm{DIP}$ and DSi in aquaculture model I were lower than those in aquaculture II (Table 1). By comparing water quality parameters in pond 1 and 3, the concentrations of $\mathrm{NH}_{4}{ }^{+}, \mathrm{NO}_{3}^{-}, \mathrm{NO}_{2}^{-}$, DIN, DON, DOP and DSi in pond 1 were higher than those in pond 3 in September and October, while the concentration of DIP in pond 1 was lower than those in pond 3. The abundances of Vibrio in pond 1 were higher than those in pond 3. The approach for judging nutrient limitation that Justić et al. (1995) proposed was used in this study. The result showed that pond 1 and 3 in October were silicon limitation (DSi $<2 \mu \mathrm{M}, \mathrm{DSi} / \mathrm{DIP}<10$ and $\mathrm{DSi} / \mathrm{DIN}<1)$. The other ponds were no nutrient limitation. 
Table 1. Water quality parameters and abundance of Vibrio in the aquaculture waters of IMTA system in 2018

\begin{tabular}{|c|c|c|c|c|c|c|c|c|c|c|c|c|c|c|c|c|c|}
\hline Date & Ponds & $\begin{array}{c}\mathbf{T} \\
\left({ }^{\circ} \mathbf{C}\right) \\
\end{array}$ & \begin{tabular}{|c|}
$S$ \\
$(g / L)$
\end{tabular} & \begin{tabular}{|c|} 
DO \\
$(\mathrm{mg} / \mathrm{L})$
\end{tabular} & $\mathbf{p H}$ & \begin{tabular}{|c|}
$\mathrm{NH}_{4}{ }^{+}$ \\
$(\mathrm{mg} / \mathrm{L})$
\end{tabular} & \begin{tabular}{|c|}
$\mathrm{NO}_{3}^{-}$ \\
$(\mathrm{mg} / \mathrm{L})$
\end{tabular} & $\begin{array}{c}\mathrm{NO}_{2}^{-} \\
(\mathrm{mg} / \mathrm{L})\end{array}$ & $\begin{array}{c}\text { DIN } \\
(\mathrm{mg} / \mathrm{L})\end{array}$ & \begin{tabular}{|c|} 
DON \\
$(\mathrm{mg} / \mathrm{L})$
\end{tabular} & $\begin{array}{c}\text { DIP } \\
(\mathrm{mg} / \mathrm{L})\end{array}$ & \begin{tabular}{|c|} 
DOP \\
$(\mathrm{mg} / \mathrm{L})$
\end{tabular} & \begin{tabular}{|c|}
$\mathbf{D S i}$ \\
$(\mathbf{m g} / \mathbf{L})$ \\
\end{tabular} & DIN/DIP & DSi/DIN & DSi/DIP & \begin{tabular}{|c|}
$\begin{array}{c}\text { Vibrio } \\
\text { (cells/L) }\end{array}$ \\
\end{tabular} \\
\hline \multirow{5}{*}{ September } & Pond 1 & 25.66 & 22.72 & 6.71 & 8.63 & 0.124 & 0.446 & 0.137 & 0.706 & 0.789 & 0.016 & 0.022 & 1.460 & 99.72 & 1.03 & 103.07 & $2.03 \times 10^{7}$ \\
\hline & Pond 3 & 26.20 & 24.28 & 6.59 & 8.60 & 0.108 & 0.233 & 0.008 & 0.348 & 0.059 & 0.022 & 0.009 & 0.909 & 35.49 & 1.31 & 46.34 & $8.60 \times 10^{6}$ \\
\hline & Pond 5 & 26.60 & 22.79 & 3.06 & 7.73 & 1.403 & 0.603 & 0.225 & 2.231 & 0.708 & 0.059 & 0.015 & 0.079 & 84.13 & 0.02 & 1.49 & $5.51 \times 10^{8}$ \\
\hline & Pond 6 & 26.80 & 22.24 & 3.06 & 7.81 & 0.674 & 0.943 & 0.149 & 1.766 & 0.598 & 0.163 & 0.003 & 0.354 & 24.03 & 0.10 & 2.41 & $1.56 \times 10^{6}$ \\
\hline & Average & 26.32 & 23.01 & 4.85 & 8.19 & 0.577 & 0.556 & 0.130 & 1.263 & 0.538 & 0.065 & 0.012 & 0.700 & 43.21 & 0.28 & 11.99 & $1.45 \times 10^{8}$ \\
\hline \multirow{5}{*}{ October } & Pond 1 & 17.74 & 26.19 & 8.45 & 8.91 & 0.059 & 0.045 & 0.001 & 0.105 & 0.414 & 0.012 & 0.012 & 0.016 & 20.04 & 0.08 & 1.52 & $9.89 \times 10^{5}$ \\
\hline & Pond 3 & 18.40 & 26.27 & 7.27 & 8.91 & 0.045 & 0.016 & B.D.L. & 0.062 & 0.279 & 0.013 & 0.011 & 0.007 & 10.59 & 0.05 & 0.58 & $9.51 \times 10^{4}$ \\
\hline & Pond 5 & 18.35 & 25.87 & 6.66 & 8.66 & 0.057 & 0.084 & 0.004 & 0.145 & 0.364 & 0.056 & 0.017 & 0.382 & 5.76 & 1.32 & 7.59 & $6.45 \times 10^{5}$ \\
\hline & Pond 6 & 18.45 & 25.72 & 4.96 & 8.31 & 0.096 & 0.252 & 0.012 & 0.360 & 0.432 & 0.081 & 0.026 & 0.431 & 9.86 & 0.60 & 5.90 & $2.25 \times 10^{4}$ \\
\hline & Average & 18.24 & 26.01 & 6.84 & 8.70 & 0.064 & 0.099 & 0.006 & 0.168 & 0.372 & 0.040 & 0.017 & 0.209 & 9.23 & 0.62 & 5.75 & $4.38 \times 10^{5}$ \\
\hline
\end{tabular}

Note: T: temperature; S: salinity; DO: dissolved oxygen; $\mathrm{NH}_{4}^{+}$: ammonium; $\mathrm{NO}_{3}^{-}$: nitrate; $\mathrm{NO}_{2}^{-}$: nitrite; DIN: dissolved inorganic nitrogen; DON: dissolved organic nitrogen; DIP: dissolved inorganic phosphate; DOP: dissolved organic phosphate; DSi: dissolved silicate; DIN/DIP, DSi/DIN and DSi/DIP are molar ratios of DIN to DIP, DSi to DIN and DSi to DIP, respectively; B.D.L.: below detectable limit 


\section{Phytoplankton community structure revealed by morphological analysis}

\section{Phytoplankton community composition}

A total of 44 taxa of phytoplankton were identified by morphological analysis in the study (Table A.1). 50.00\% of the identified taxa belongs to Bacillariophyta, followed by Dinophyta, Cryptophyta, Chlorophyta and Cyanophyta with 20.45\%, 11.36\%, 9.09\% and $6.82 \%$, respectively. Euglenophyta was represented by only one species. Only three species, Cyclotella sp. Nitzschia sp.1 and Gymnodinium spp. were detected by morphological analysis at all samples.

\section{Temporal and spatial variations of phytoplankton abundance}

Phytoplankton abundance indicated by cell density in September $\left(4.91 \times 10^{5}\right.$ cells/L) was lower than those in October $\left(8.83 \times 10^{6}\right.$ cells/L). The phytoplankton average abundance in aquaculture model I was higher than that in aquaculture model II in September and October. By comparing pond 1 and 3, the phytoplankton abundance in pond 1 was lower than those in pond 3 (Fig. 2).

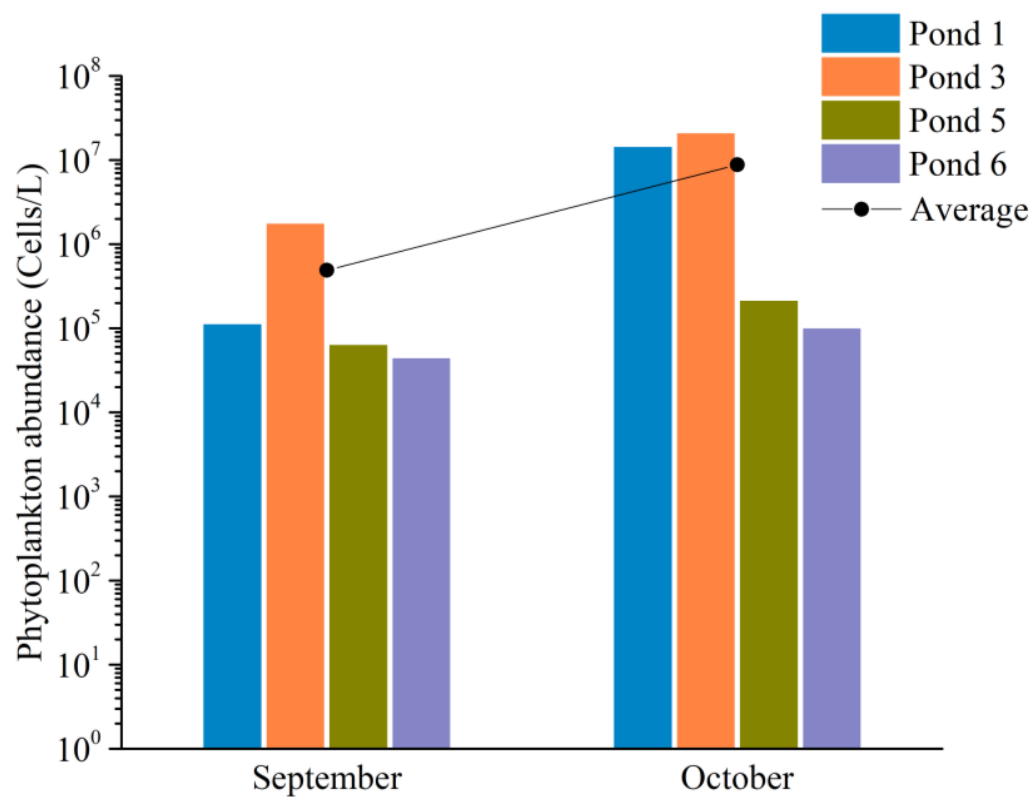

Figure 2. Temporal and spatial variations of phytoplankton abundance in the IMTA system revealed by morphological analysis. Aquaculture model I consists of pond 1 where F. chinensis were co-cultured with $P$. trituberculatus and $O$. niloticus together and pond 3 where $M$. meretrix stocked. Aquaculture model II consists of pond 5 and 6 where F. chinensis, $P$. trituberculatus and M. mercenaria cultured together in the same pond

In September, diatoms were the most abundant species, which accounted for $59.09-96.41 \%$ of the total phytoplankton in pond 1,5 and 6 . The relative abundances of euglenophyte and diatoms were higher than other species in pond 3 (Fig. 3). In October, diatoms were the most abundant group which contributed over $99 \%$ of the total phytoplankton in pond 1 and 3, while the abundance of euglenophyte was the highest in ponds 5 and 6 (Fig. 3). 


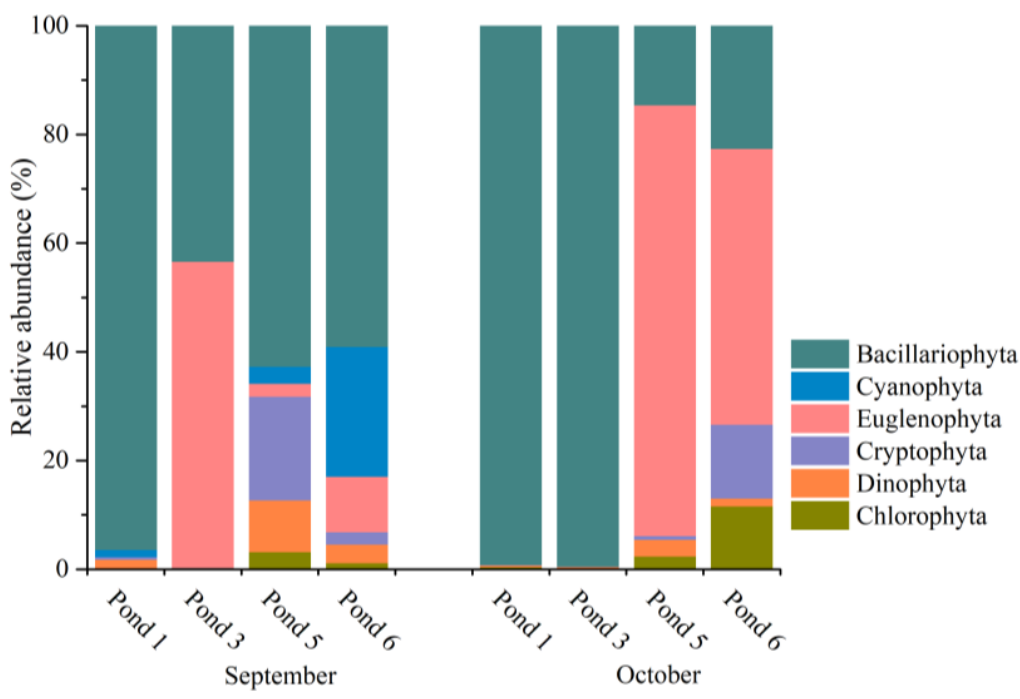

Figure 3. Temporal and spatial variations of relative abundance of phytoplankton at the phylum level in the IMTA system revealed by morphological analysis. Aquaculture model I consists of pond 1 where $F$. chinensis were co-cultured with $P$. trituberculatus and $O$. niloticus together and pond 3 where M. meretrix stocked. Aquaculture model II consists of pond 5 and 6 where F. chinensis, P. trituberculatus and M. mercenaria cultured together in the same pond

\section{Dominant species of phytoplankton}

In September, Diatoms, Cyclotella sp. and Cyclotella meneghiniana Kuetzing were the dominated species in pond 1, which accounted for $70.85 \%$ and $11.21 \%$ of the total abundance. There were three dominant species in pond 3 including Eutreptiella sp., Melosira sp. and Cyclotella sp., which contributed to about $97.99 \%$ of the total abundance. There were two (Cyclotella sp. and Teleaulax acuta) and four (Mastigocoleus sp., Cyclotella sp., Surirella sp. and Eutreptiella sp.) species were dominant in pond 5 and 6, respectively. Cyclotella sp. was one of the dominated species in all ponds in September (Table 2).

Table 2. Dominant species, cell density and dominance of phytoplankton in the IMTA system

\begin{tabular}{|c|c|c|c|c|}
\hline Time & Ponds & Dominant species & $\begin{array}{c}\text { Cell density } \\
\text { (cells/L) }\end{array}$ & Dominance \\
\hline \multirow{11}{*}{ September } & \multirow[t]{2}{*}{ Pond 1} & Cyclotella sp. & $7.90 \times 10^{4}$ & 0.71 \\
\hline & & Cyclotella meneghiniana Kuetzing & $1.25 \times 10^{4}$ & 0.11 \\
\hline & \multirow{2}{*}{ Pond 3} & Eutreptiella $\mathrm{sp}$. & $9.81 \times 10^{5}$ & 0.56 \\
\hline & & Melosira sp. & $4.23 \times 10^{5}$ & 0.24 \\
\hline & \multirow{3}{*}{ Pond 5} & Cyclotella sp. & $3.06 \times 10^{5}$ & 0.18 \\
\hline & & Cyclotella sp. & $2.60 \times 10^{4}$ & 0.41 \\
\hline & & Teleaulax acuta & $1.05 \times 10^{4}$ & 0.17 \\
\hline & \multirow[t]{4}{*}{ Pond 6} & Mastigocoleus sp. & $8.50 \times 10^{3}$ & 0.19 \\
\hline & & Cyclotella sp. & $8.00 \times 10^{3}$ & 0.18 \\
\hline & & Surirella sp. & $6.50 \times 10^{3}$ & 0.15 \\
\hline & & Eutreptiella sp. & $4.50 \times 10^{3}$ & 0.10 \\
\hline \multirow{5}{*}{ October } & \multirow{5}{*}{$\begin{array}{l}\text { Pond } 1 \\
\text { Pond } 3 \\
\text { Pond } 5 \\
\text { Pond } 6\end{array}$} & Leptocylindrus danicus & $1.39 \times 10^{7}$ & 0.98 \\
\hline & & Leptocylindrus danicus & $2.06 \times 10^{7}$ & 0.99 \\
\hline & & Eutreptiella sp. & $1.68 \times 10^{5}$ & 0.79 \\
\hline & & Eutreptiella sp. & $5.05 \times 10^{4}$ & 0.51 \\
\hline & & Pyramimonas sp. & $1.05 \times 10^{4}$ & 0.11 \\
\hline
\end{tabular}


In October, Leptocylindrus danicus was the only dominant species in pond 1 and 3, which reached a high cell density of $1.39 \times 10^{7}$ and $2.06 \times 10^{7}$ cells/L with $97.70 \%$ and $99.24 \%$ of the total abundance, respectively. Eutreptiella sp. was the only dominant species $\left(79.25 \%\right.$ of the total) in pond 5 , with cell density at $1.68 \times 10^{5}$ cells/L. Eutreptiella sp. and Pyramimonas sp. dominated in pond 6 (Table 2).

\section{Phytoplankton diversity}

Shannon indices were ranged from 1.09 to 2.46 in September, and ranged from 0.06 to 1.89 in October. Phytoplankton diversity in September was higher than those in October in all ponds. The two surveys showed that phytoplankton diversity in aquaculture model I was lower than that in aquaculture model II. By comparing pond 1 and 3, the phytoplankton diversity in pond 1 was higher than that in pond 3 (Fig. 4).

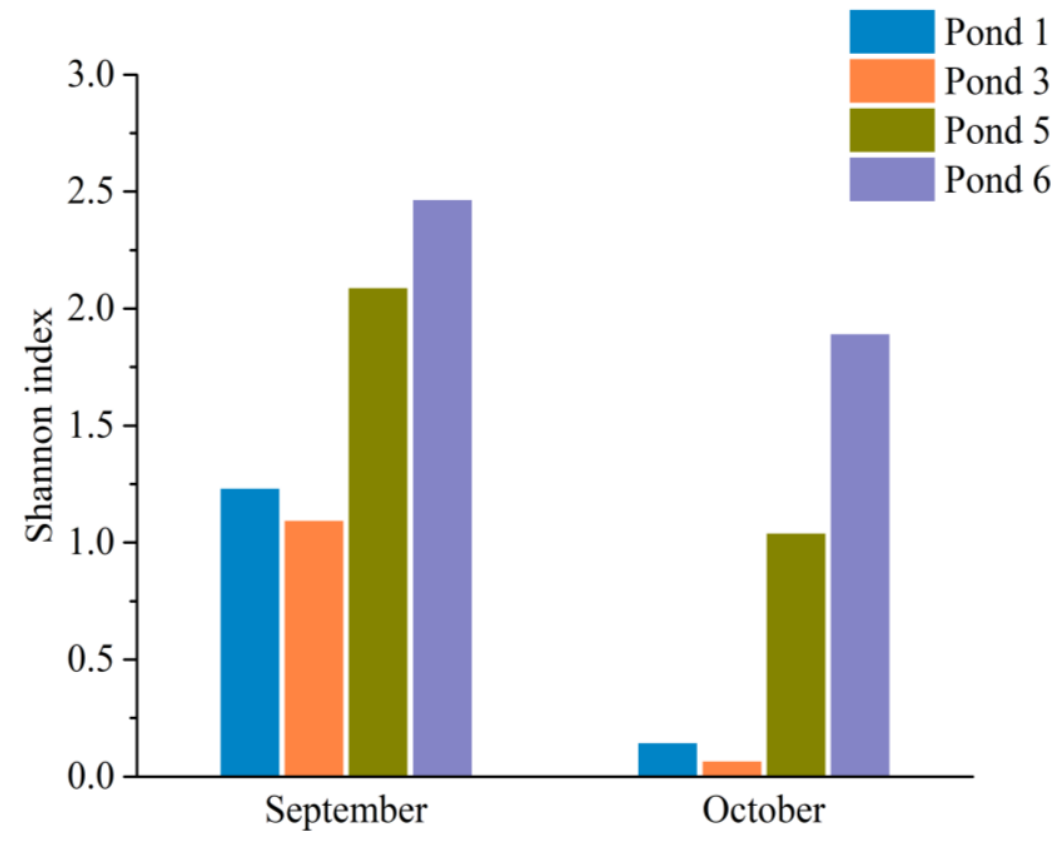

Figure 4. Phytoplankton diversity revealed by morphological analysis. Aquaculture model I consists of pond 1 where $F$. chinensis were co-cultured with $P$. trituberculatus and $O$. niloticus together and pond 3 where M. meretrix stocked. Aquaculture model II consists of pond 5 and 6 where F. chinensis, P. trituberculatus and M. mercenaria cultured together in the same pond

\section{Phytoplankton community structure revealed by high-throughput sequencing}

\section{High-throughput sequencing data statistics}

A total of 406,246 raw reads were obtained using high-throughput Illumina sequencing for all samples, and the number of reads for each sample ranged from 31,364 to 64,004 . After quality and chimera checking and removal of the low-quality reads, a total of 374,428 clean reads were obtained. The average reads length was 388 nucleotides. The reads for all samples were classified into 162 OTUs, ranging from 34 to 103 OTUs, at a $97 \%$ similarity level (Table 3). 
Table 3. Numbers of sequences in quality control analysis

\begin{tabular}{c|c|c|c|c|c|c}
\hline Date & Pond Number & Raw Reads & Clean Reads & Total OTUs & Phytoplankton Reads & Phytoplankton OTUs \\
\hline \multirow{5}{*}{ September } & Pond 1 & 31,364 & 27,270 & 34 & 16,821 & 26 \\
& Pond 3 & 64,004 & 55,587 & 38 & 35,708 & 28 \\
& Pond 5 & 56,775 & 52,596 & 46 & 27,625 & 31 \\
& Pond 6 & 49,022 & 47,125 & 103 & 27,489 & 42 \\
\hline \multirow{5}{*}{ October } & Pond 1 & 54,764 & 51,338 & 66 & 47,083 & 40 \\
& Pond 3 & 61,902 & 57,306 & 89 & 51,542 & 40 \\
& Pond 5 & 37,164 & 33,930 & 65 & 23,916 & 30 \\
& Pond 6 & 51,251 & 49,276 & 62 & 38,539 & 30 \\
\hline Sum & & 406,246 & 374,428 & 162 & 268,723 & 68 \\
\hline
\end{tabular}

Taxa were assigned to the representative sequence of each OTU using the NCBI database. According to the taxonomic information, the sequences that were annotated as eukaryota and bacteria accounted for $63.98 \%$ and $35.57 \%$, respectively (Fig. 5). At phylum level, Cyanobacteria sequences accounted for the greatest proportion of the total sequences (28.73\%), followed by Bacillariophyta (24.04\%), Chlorophyta (6.04\%), Proteobacteria (6.00\%), Haptophyta (5.63\%), Euglenophyta (4.78\%) and Cryptophyta (1.80\%). The sequences of Ochrophyta, Verrucomicrobia, Bacteroidetes, Raphidophyta, Dinophyta and Firmicutes accounted for less than 1\% of the total sequences. 268,723 sequences ranging from 16,821 to 51,542 were assigned to phytoplankton after the exclusion of bacteria (except cyanobacteria) and unclassified sequences (Table 3). The number of phytoplankton sequences was randomly rarefied to 16,821 per sample, which were used in further analyses of phytoplankton community structure and diversity.

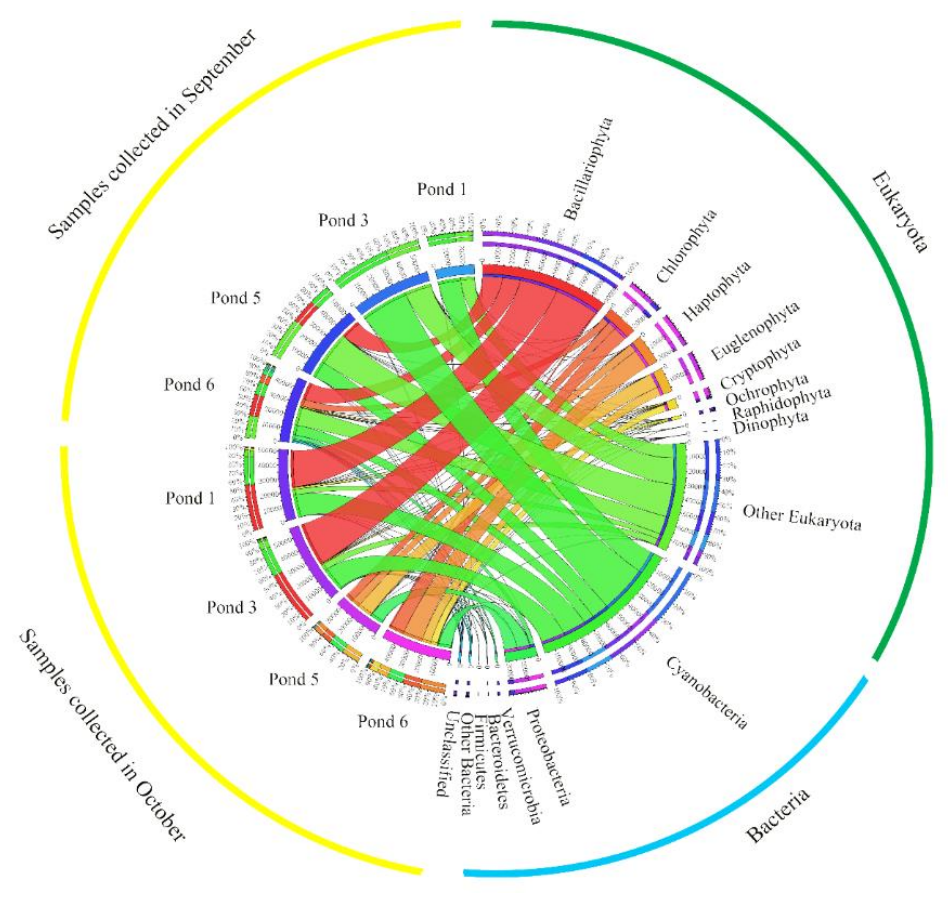

Figure 5. Circular representation of sequences assigned to eukaryota, bacteria and unclassified. Aquaculture model I consists of pond 1 where F. chinensis were co-cultured with $P$. trituberculatus and $O$. niloticus together and pond 3 where M. meretrix stocked. Aquaculture model II consists of pond 5 and 6 where F. chinensis, P. trituberculatus and M. mercenaria cultured together in the same pond 


\section{Phytoplankton community composition}

A total of 68 OTUs assigned to phytoplankton were identified by high-throughput sequencing in the study (Table 3). The OTUs number of Cyanophyta was the highest (30.88\%), followed by Chlorophyta (29.41\%), Bacillariophyta (16.18\%) and Dinophyta (5.88\%). Cryptophyta, Ochrophyta and Haptophyta were represented by three OTUs, Euglenophyta was represented by two OTUs, and Raphidophyta was represented by only one OTU. Among these OTUs, OTU6, OTU94, OTU108, OTU148, which were affiliated with Cyanobium gracile, Synechococcus sp. WH 8020, Nannochloropsis oculata and Cyclotella sp. WC03_2, respectively, existed in all ponds (Table A.2).

\section{Relative abundance of phytoplankton}

In aquaculture mode I, Cyanophyta was the most dominant phylum in September with relative abundance $>99 \%$, while Bacillariophyta was the dominant phylum in October with relative abundance $>59 \%$ (Fig. 6a). At genus level, Cyanobium was the most abundant in September, while Leptocylindrus was the most dominated, followed by Cyanobium, Synechococcus and Cerataulina in October (Fig. 6b).
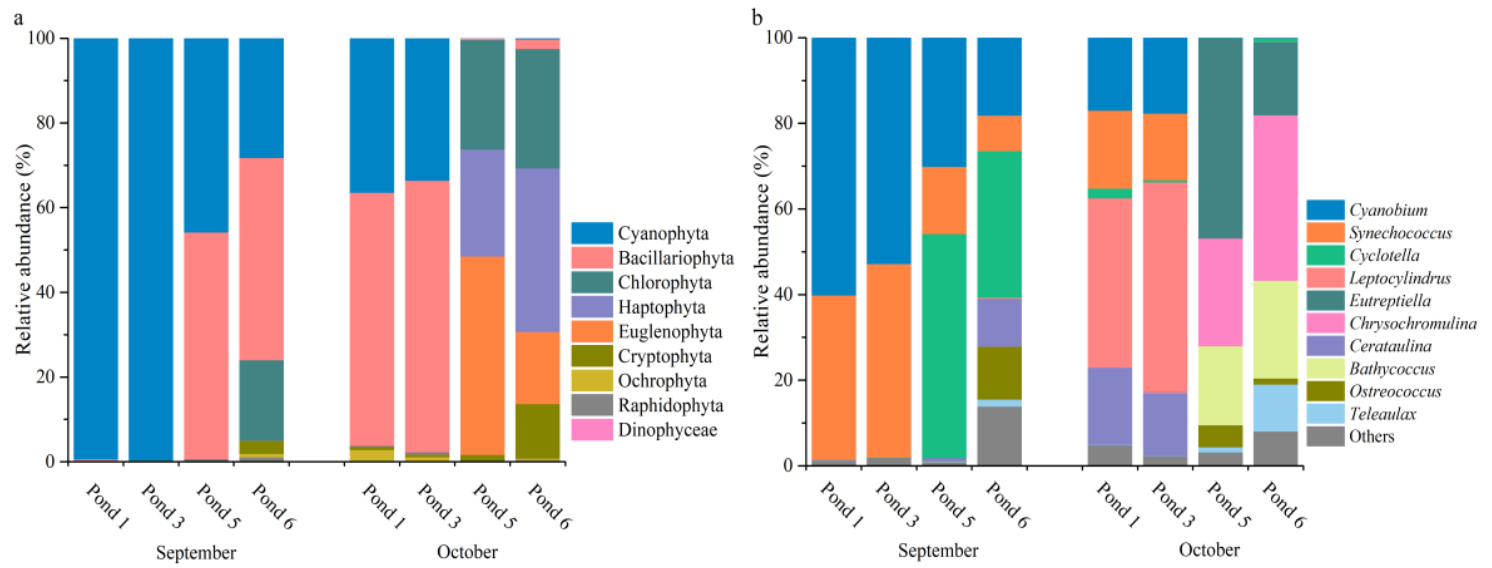

Figure 6. Relative abundance of phytoplankton at the phylum (a) and genus (b) levels. Aquaculture model I consists of pond 1 where F. chinensis were co-cultured with

$P$. trituberculatus and $O$. niloticus together and pond 3 where M. meretrix stocked. Aquaculture model II consists of pond 5 and 6 where F. chinensis, P. trituberculatus and M. mercenaria cultured together in the same pond

In aquaculture mode II, Bacillariophyta was the most dominant phylum, followed by Cyanophyta in September, while Euglenophyta, Haptophyta and Chlorophyta were the abundant phylum in October (Fig. 6a). At genus level, Cyclotella whose relative abundance was over 34\%, was the most dominant genus, followed by Cyanobium in September, while Eutreptiella, Chrysochromulina and Bathycoccus were the abundant genus in October (Fig. 6b).

\section{Phytoplankton diversity}

Shannon indices were ranged from 1.72 to 2.42 in September and ranged from 1.44 to 2.06 in October. Phytoplankton diversity in September was lower than those in October in aquaculture model I, while phytoplankton diversity in September were 
higher than those in October in aquaculture model II. By comparing pond 1 and 3, the phytoplankton diversity in pond 1 was higher than that in pond 3 in October (Fig. 7).

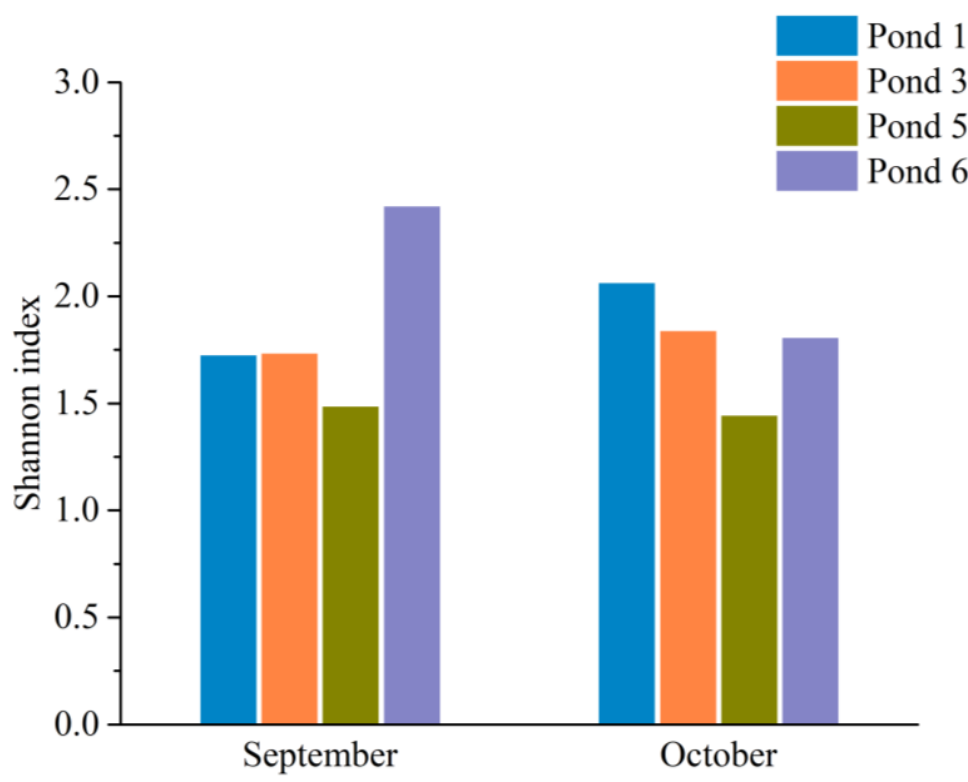

Figure 7. Phytoplankton diversity revealed by high-throughput sequencing. Aquaculture model I consists of pond 1 where $F$. chinensis were co-cultured with $P$. trituberculatus and $O$. niloticus together and pond 3 where M. meretrix stocked. Aquaculture model II consists of pond 5 and 6 where F. chinensis, P. trituberculatus and M. mercenaria cultured together in the same pond

\section{Correlations between phytoplankton community and water quality}

The relationship between the dominated species of phytoplankton revealed by morphological analysis and water quality parameters in the IMTA system were examined by direct gradient analysis using redundancy analysis (Fig. $8 a$ ). The first axis was positively correlated with the $\mathrm{S}(0.6066)$ and $\mathrm{pH}(0.6023)$, and negatively correlated with the $\mathrm{T}(-$ $0.6595)$, DSi (-0.6087), DSi/DIP (-0.5620) and DSi/DIN (-0.5469). The second axis was positively correlated with DIN/DIP (0.8577), DON (0.7027), DIN (0.6518) and negatively correlated with S (-0.7241). These results showed that T, S, pH, DIN, DON, DSi, DIN/DIP, DSi/DIN and DSi/DIP greatly influenced on the phytoplankton community. The dominant species L. danicus was negatively correlated with the DIN, DIP, DSi, DON, DOP concentrations, DIN/DIP, DSi/DIN, DSi/DIP and Vibrio abundance. The euglenophyte Eutreptiella sp. and green algae Pyramimonas sp. had negative correlation with DIN, DON concentrations, DIN/DIP and Vibrio abundance and positive correlation with DIP, DOP concentrations, DSi/DIN and DSi/DIP. The relationships between abundant genus of phytoplankton revealed by high-throughput sequencing and water quality parameters in the IMTA system were examined by direct gradient analysis using canonical correspondence analysis (Fig. 8b). The first axis was positively correlated with the DOP (0.5697), DSi/DIN (0.5164) and negatively correlated with the DIN/DIP (-0.6759), and the second axis was positively correlated with the $\mathrm{S}(0.7849), \mathrm{pH}(0.6670)$ and negatively correlated with the $\mathrm{T}$ (-0.8311), DIN (-0.6981), DSi (-0.6653), DIN/DIP (-0.6401) and DSi/DIP (-0.6074). These results showed that the T, S, pH, DIN, DOP, DSi, DIN/DIP, DSi/DIN and DSi/DIP had the greatest influences on the phytoplankton community. The diatom, Leptocylindrus was 
negatively correlated with the DIN, DIP, DSi, DON, DOP concentrations, DIN/DIP, DSi/DIN, DSi/DIP and Vibrio abundance. The euglenophyte Eutreptiella, green algae Bathycoccus and Ostreococcus, and haptophyte Chrysochromulina showed negative correlation with DIN, DON concentrations, DIN/DIP and Vibrio abundance and positive correlation with DIP, DOP concentrations, DSi/DIN, while the cyanophytes, Cyanobium and Synechococcus showed positive correlations with DIN, DON concentrations, DIN/DIP and Vibrio abundance and negative correlation with DSi/DIN.
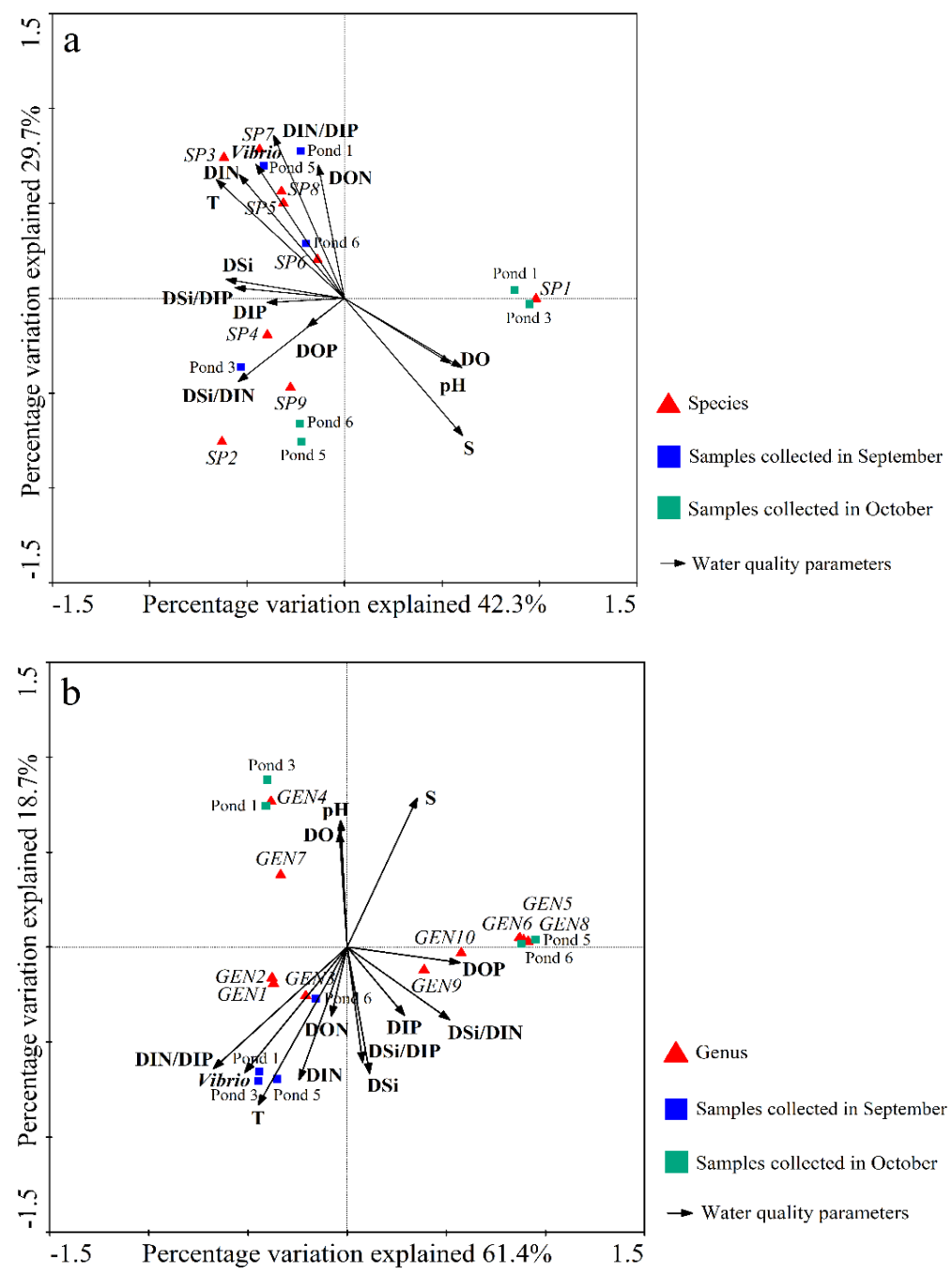

Figure 8. Direct gradient analysis of phytoplankton community revealed by morphological analysis (a) and high-throughput sequencing (b) methods and water quality parameters. The numbers with letter represent the relevant species or genus: SP1 Leptocylindrus danicus, SP2 Eutreptiella sp., SP3 Cyclotella sp., SP4 Melosira sp., SP5 Surirella sp., SP6 Mastigocoleus sp., SP7 Cyclotella meneghiniana, SP8 Teleaulax acuta, SP9 Pyramimonas sp., GEN1 Cyanobium, GEN2 Synechococcus, GEN3 Cyclotella, GEN4 Leptocylindrus, GEN5 Eutreptiella, GEN6 Chrysochromulina, GEN7 Cerataulina, GEN8 Bathycoccus, GEN9 Ostreococcus, GEN10 Teleaulax. Aquaculture model I consists of pond 1 where F. chinensis were co-cultured with $P$. trituberculatus and $O$. niloticus together and pond 3 where M. meretrix stocked. Aquaculture model II consists of pond 5 and 6 where F. chinensis, P. trituberculatus and M. mercenaria cultured together in the same pond 


\section{Discussion}

\section{Phytoplankton community structure revealed by two methods}

In the late stage of aquaculture, the nutrients in the residual feeds are accumulated constantly in the pond water, leading to eutrophication and subsequently the flourishing of phytoplankton (Huang et al., 2016). Some phytoplankton groups, such as diatoms and green algae, are beneficial due to their high nutritional value and contribution to water quality (Roy and Pal, 2015; Brito et al., 2016). Other groups, such as cyanobacteria and dinoflagellates, are harmful because of their low nutritional value and toxins they produced (Sinden and Sinang, 2016; Pérez-Morales et al., 2017). Therefore, understanding the phytoplankton community is critical for good management and high yield in pond culture practice. In this study, 9 phyla of phytoplankton were identified by both 2 methods, and Bacillariophyta Cyanophyta and Euglenophyta were the dominant group. It is notable that phyla Ochrophyta, Haptophyta and Raphidophyta were only found by the high-throughput sequencing (Fig. 3, Fig. 6). A total of 60 genera were detected by both methods, but only 12 genera (Cerataulina, Chaetoceros, Cyclotella, Cylindrotheca, Leptocylindrus, Nitzschia, Gymnodinium, Pyramimonas, Nephroselmis, Teleaulax, Chroomonas and Eutreptiella) were consistent. Therefore, the combination of molecular and morphological techniques will be useful to get a comprehensive understanding of phytoplankton communities in aquatic ecosystems (Qiao et al., 2019).

In September, diatom was the dominant group in all ponds and the relative abundance of Cyanophyta was under $24 \%$ revealed by morphological analysis. While, cyanophyte of picoplanktonic cell sizes $(0.2$ to $2.0 \mu \mathrm{m})$ accounted for $28.26-99.54 \%$ of total phytoplankton abundance revealed by high-throughput sequencing, including Cyanobium, Synechococcus and Synechocystis (Fig. 6b), which were too small to observe by microscope. Cyanophytes had strong tolerance to pollutants, and often dominated the phytoplankton community (>88\%) in shrimp ponds (Alonso-Rodriguez and Paez-Osuna, 2003). Studies have shown that the blue-green algae bloom, caused by changes in the weather, eutrophication of water, or imbalance between carbon, nitrogen and phosphorous in the water, results in deterioration of water quality and is highly detrimental to aquaculture organisms (Kong et al., 2013; Wu et al., 2013; Fu et al., 2015; Ajin et al., 2016). Furthermore, bloom-forming blue-green algae can produce a diverse array of secondary metabolites, some of which are toxic to plants, invertebrates and vertebrates including humans at naturally occurring concentrations (Smith et al., 2008; Meriluoto et al., 2017; Huisman et al., 2018). Therefore, it was necessary to take some measures (the reduction of undesirable algae via physical/chemical methods, and post-harvest treatment techniques) to control noxious algal blooms or remedy their effects (Smith et al., 2008). In October, the diatom, L. danicus was the most dominated species in aquaculture model I revealed by both methods, which reached a high cell density of $10^{7}$ cells/L. L. danicus is 3-13 $\mu \mathrm{m}$ in diameter, 22-75 $\mu \mathrm{m}$ in pervalvar length, forming filamentous chains (Nanjappa et al., 2013). This alga has a fast growth rate and the potential to form auxospores and resting spores, which is clear advantages to survival (Ajani et al., 2016). Studies have shown that L. danicus is a major component of coastal phytoplankton communities (Nanjappa et al., 2013; Ajani et al., 2016). In aquaculture model II, the euglenophyte (Eutreptiella) was dominated revealed by both methods. Phototrophic euglenophytes have diverse roles in marine planktonic food webs: they are primary producers (Kingston, 1999); predators that feed on prey species such as eubacteria and picocyanobacteria (Yoo et al., 2018); and prey for diverse grazers such as heterotrophic dinoflagellates and ciliates (Jeong et al., 2011). In addition, some 
euglenophytes could lead to dense blooms in diverse environments and produce the alkaloid toxin causing significant fish kills (Kingston, 2002; Zimba et al., 2017). Because of lacking of cell walls, euglenoids are very sensitive to environment change (Liu, 2009). In a natural environment, any action leading to a significant increase in the organic matter present will cause a marked cell deformation (Conforti, 1998), and might even cause algae dead and deterioration of water quality.

Except for the dominant species, some attention should also be paid to the toxic algae that might cause red tides. In this study, the raphidophyte, Heterosigma akashiwo was detected in pond 3 and 6 by high-throughput sequencing (Fig. 6a, Table A.2), but was missing in morphological analysis. This might be related to its lack of a cell wall. The addition of normal preservatives such as Lugol's solution has been shown to result in rapid cell clumping in some studies (Tyrrell et al., 2001; O'Halloran et al., 2006), making enumeration by light microscopy challenging. H. akashiwo has been implicated in fish killing blooms (Engesmo et al., 2016). Therefore, more attention should be paid to its potential toxicity to shrimp, crab and clam.

\section{Relationships between water quality and phytoplankton community}

During an aquaculture production cycle, feed supply in shrimp ponds increases concomitantly with the stocking biomass, which can induce an increasing eutrophication level in the pond ecosystem (Burford et al., 2003). Subsequently there is an increase in algal biomass. Phytoplankton communities are primary producers and consumers of dissolved oxygen and maintaining the stability in the stocking biomass and metabolic activity of phytoplankton communities is essential to provide a suitable environment for cultured animals. Changes in the phytoplankton community due to the increase in nutrients may result in outbreaks of harmful algal blooms (Alonso-Rodriguez and Paez-Osuna, 2003). Our results indicated that $\mathrm{T}, \mathrm{S}, \mathrm{pH}, \mathrm{DIN}, \mathrm{DSi}$ concentrations, DIN/DIP, DSi/DIN and DSi/DIP can affect the phytoplankton community structure inferred from both methods.

The cyanophytes (Cyanobium and Synechococcus) were dominated in September (Fig. $6 a$ ), while diatom (Leptocylindrus) and euglenophyte (Eutreptiella) were dominated in October (Fig. 3, Fig. 6a). On the one hand, the temperature in September $\left(26^{\circ} \mathrm{C}\right)$ was suitable for the outbreak of cyanophytes (Paerl and Huisman, 2008); on the other hand, the cyanophytes could out-compete other phytoplankton organisms due to their high nutrient affinity, especially under conditions of phosphorus or nitrogen limitation (Moisander et al., 2003). Furthermore, some of the species can fix free nitrogen, making them superior competitors (González-Madina et al., 2019). In the present study, the cyanophytes showed positive correlation with DIN/DIP and negative correlation with DIP and DOP concentrations (Fig. 8). The result indicated that cyanophytes might be phosphorus limitation. Studies have shown that phosphorus availability is one of the main factors linked to the abundance of cyanobacteria, and cyanobacterial dominance increased with the increases of the total phosphorus concentration (Downing et al., 2011). Therefore, controlling internal phosphorus loading in ponds could be used to control cyanobacterial blooms that are likely to increase in frequency and intensity in response to eutrophication (Bormans et al., 2016). The cyanobacteria can fix nitrogen and use the organic nitrogen as their nitrogen resource, whose demand for inorganic nitrogen was lower than that of eukaryotes (Glibert et al., 2004). That might be the reason why the DIN concentration in September was higher than that in October (Table 1). The high DIN concentrations provided suitable nutrient conditions for the outbreak of diatom (L. danicus) and euglenophyte (Eutreptiella) in October. Studies suggested that diatom (L. danicus) and 
euglenophyte favors nutrient-enriched seawater (Olli et al., 1996; Kingston, 2002; Zhu et al., 2009). In this study, the dominant species $L$. danicus was negatively correlated with the DIN, DIP, DSi, DON, DOP concentrations, DIN/DIP, DSi/DIN and DSi/DIP (Fig. 8). The results indicated that $L$. danicus might be able to utilize various forms of nutrients. Nutrient enrichment experiments indicated that nitrate, urea and phosphate addition promoted the growth of L. danicus (Zhu et al., 2009). The euglenophyte (Eutreptiella) showed negative correlation with DIN concentration and DIN/DIP (Fig. 8), which indicated euglenophyte could prefer to use DIN. Investigation reveals that high population of Eutreptiella was kept in the inner bay during the spring and summer associated with high DIN after river discharge following rainfall, suggesting that DIN supply might have triggered the increase of Eutreptiella population (Lee et al., 2016). The density and biomass of euglenophyte in heavily polluted areas were markedly higher than in a relatively clean area, which are used as biological indicators of the organic pollution of water (Stonik and Selina, 2001).

Statistical relationships between Vibrio and environmental parameters have suggested that high water temperature (Thompson et al., 2004) as well as low salinity favor the growth of Vibrio (Wright et al., 1996; DePaola et al., 2003). This is consistent with the results, which found positive correlation between Vibrio abundance and temperature and negative correlation between Vibrio abundance and salinity in this study (Fig. 8). In addition, Vibrio abundance had significant positive correlation with $\mathrm{NH}_{4}{ }^{+}(p<0.01)$, suggesting that Vibrio was more likely to grow in the high ammonia water. Some studies indicated the importance of phytoplankton biomass, or phytoplankton community composition, for Vibrio growth (Turner et al., 2009). In this study, the relationship between phytoplankton community and Vibrio abundance were analyzed. The results showed that the diatoms and green algae were negatively correlated with Vibrio abundance, while the cyanophytes showed positive correlations with Vibrio abundance (Fig. 8). It can be inferred that diatoms and chlorophytes might inhibit the development of Vibrio, while cyanophytes bloom might be beneficial to the growth of Vibrio. Studies found that phytoplankton associated with green water, such as diatoms (Chaetoceros calcitrans, Nitzchia sp., Skeletonema costatum, Phaeodactylum tricornutum) and green algae (Chlorella spp., Nannochlorum sp., Tetraselmis suecica) can effectively inhibit the multiplication of Vibrio (Lio-Po et al., 2005; Makridis et al., 2006). On the contrary, some phytoplankton (such as cyanophytes) might facilitate the proliferation of Vibrio in their natural environment. Studies have shown that cyanobacterial-derived organic matter has been reported as an important growth factor for Vibrio (Eiler et al., 2007). In addition, it was demonstrated by both laboratory and field studies that cyanobacteria can play important roles as environmental reservoirs for Vibrio (Tamplin et al., 1990; Islam et al., 2004; Baffone et al., 2006). It was observed by phasecontrast, fluorescent, and immunoelectron microscopy that Vibrio were located within the mucilaginous sheath of cyanobacteria, and could multiply and maintain their progeny in cyanobacteria (Islam et al., 1999).

\section{Aquaculture models influencing water quality and phytoplankton community structure}

One of the key environmental concerns regarding aquaculture is the accumulation of nutrients, which can cause adverse effects in water quality deteriorations and the form of harmful algae blooms within ponds (Huang et al., 2016). Studies have shown that IMTA not only have higher nutrient use efficiency than monoculture, but also can improve aquaculture production (Wang et al., 1999; Tian et al., 2001; Hosseini Aghuzbeni et al., 2017; Li et al., 2019). However, the efficiency and ecological influence of pond aquaculture largely depends on species combination (Jena et al., 2002; Rahman and Verdegem, 2007). 
In the present study, there were two aquaculture models. Aquaculture model I was consisting of a culture pond (pond 1), where shrimps were co-cultured with crab and tilapia together, and a biological purification pond (pond 3) with clam stocked. Aquaculture model II was polyculture of shrimp, crab and clam together in the same pond (Fig. 1). Investigations revealed that $\mathrm{DIN}\left(\mathrm{NH}_{4}{ }^{+}, \mathrm{NO}_{3}{ }^{-}, \mathrm{NO}_{2}{ }^{-}\right)$concentrations in pond 3 were lower than those in pond 1 (Table 1), which indicated that aquaculture pond attached to clam pond could be effectively purify water quality (Jones et al., 2002). In addition, the average concentrations of DIN in aquaculture model I were lower than those in aquaculture model II (Table 1). Therefore, the combination of aquaculture species should be reasonably selected according to different ecological niches.

Hierarchical clustering tree on OTU level showed that phytoplankton community structure in pond 1 was similar with that in pond 3 , while phytoplankton community structure in pond 5 was similar with that in pond 6 (Fig. 9). Phytoplankton community structure in aquaculture waters is not only affected by water temperature, salinity, $\mathrm{pH}$ and nutrients, but also controlled by the top-down effect of aquaculture species (Hulot et al., 2018; Dantas et al., 2019).

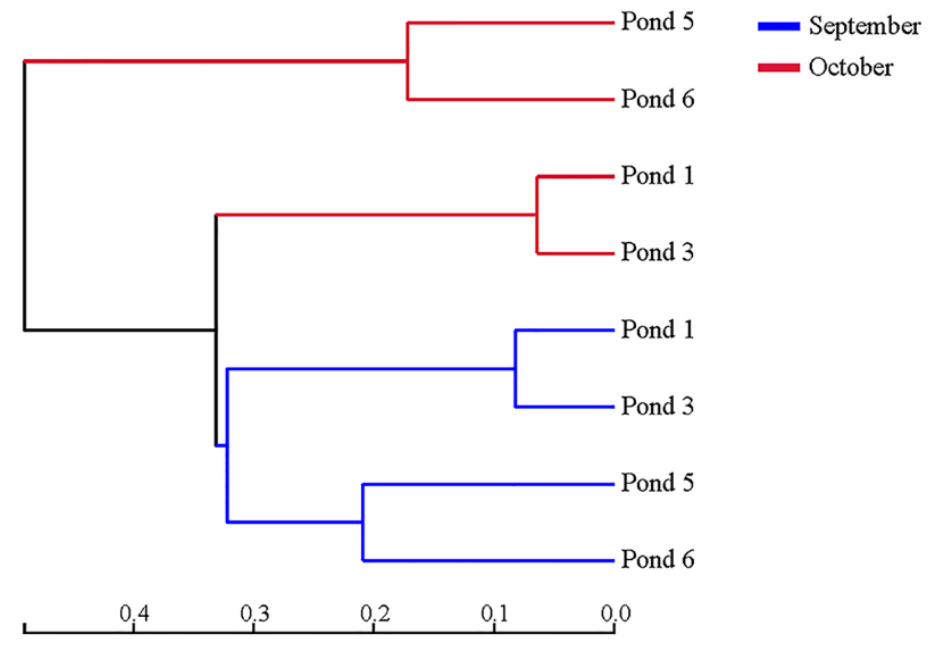

Figure 9. Hierarchical clustering tree on OTU level revealed by high-throughput sequencing. Aquaculture model I consists of pond 1 where F. chinensis were co-cultured with $P$. trituberculatus and $O$. niloticus together and pond 3 where M. meretrix stocked. Aquaculture model II consists of pond 5 and 6 where F. chinensis, P. trituberculatus and M. mercenaria cultured together in the same pond

Tilapia is a filter-feeding omnivorous fish that can have a negative effect on phytoplankton resources (Menezes et al., 2010; Sun et al., 2011) and their selective feeding regime can also unbalance phytoplankton constituents of the water column (Figueredo and Giani, 2005). Study has shown that tilapia feeds selectively on large algae (Figueredo and Giani, 2005). The dominant group in pond 1 in September was picocyanobacteria (Cyanobium, Synechococcus and Synechocystis) (Fig. 6b), which were too small $(<3 \mu \mathrm{m})$ to be ingested. In addition, feeding selectivity of tilapia changed slightly as their weight increased, resulting in a shift in phytoplankton community (Abdel-Tawwab, 2011). Investigations found that tilapia could select Cyanobacteria and Euglenophyceae at all fish weights, meanwhile Chlorophyceae and Bacillariophyceae were eaten with slight selectivity at larger weights (Abdel-Tawwab, 2011). And the strength of its effects on plankton 
community should decrease with increasing plankton biomass, e.g., during an algal bloom (Vasconcelos et al., 2018). These might be the reason why diatoms dominated in aquaculture model I, while euglenophytes were abundant in aquaculture model II in October (Fig. 3).

Clams growth is highly adaptable to a wide range of temperatures and diet varieties making them a highly successful global aquaculture species well suited for IMTA (Troell et al., 2009). Clams are filter feeders that acquire energy filtering suspended particles such as phytoplankton and detritus (Reid et al., 2010; Macdonald et al., 2011; Sarà et al., 2012). Their selective feeding behavior could also affect phytoplankton community structure (Newell, 2004). In this study, some picophytoplankton including Cyanobacteria (Cyanobium and Synechococcus) and chlorophytes (Bathycoccus and Ostreococcus) were abundant revealed by high-throughput sequencing (Fig. O). Studies have shown that larger nanoplankton cells may be preferentially removed in comparison with smaller picoplankton species that are retained less efficiently on the gill of most bivalve species (Newell, 2004), leading to the situation where picoplankton become relatively more abundant than larger species in areas with clam populations (Newell et al., 2009). Except for cell size, feeding selectivity was also dependent on nutritional value and swimming ability of phytoplankton (Bricelj et al., 1984; Zhuang et al., 2004). Cyanobacteria can produce microcystins, which have caused detrimental effects in aquatic organisms (Smith et al., 2008). Studies found that cyanobacteria could be recognized by selective filter-feeding invertebrates as nutritionally poor or toxic and the formation of colonies or elongated filaments could mechanically interfere with grazing (Smith et al., 2008). Therefore, one of the reasons cyanobacteria were dominated in September (Fig. 6) might be related to the low grazing pressure of clam. Eutreptiella, Chrysochromulina and Teleaulax have flagella, with which they can move freely (Edvardsen and Paasche, 1992; Rhodes and Burke, 1996; Stonik, 2007; Xing et al., 2008; Laza-Martínez et al., 2012). Their motility made them less easily ingested by clam, which might be one reason for its higher relative abundance.

\section{Conclusions}

In summary, Bacillariophyta, Cyanophyta and Euglenophyta were the dominant group in IMTA system in the late stage of aquaculture revealed by both morphological analysis and high-throughput sequencing. The dominant phytoplankton of the IMTA pond system in which clams were reared in a separate pond has changed from cyanophytes to diatoms from September to October, and it has changed from diatoms and cyanophytes to euglenophytes, haptophytes and green algae in the IMTA pond with shrimp, crab and clam together. The variables of temperature, salinity, $\mathrm{pH}, \mathrm{DIN}$, DSi concentrations, DIN/DIP, DSi/DIN and DSi/DIP were the main factors influencing the phytoplankton community structure. The relationship between phytoplankton community and Vibrio abundance indicated that diatoms and chlorophytes might inhibit the development of Vibrio, while cyanophytes bloom might be beneficial to the growth of Vibrio. A detailed description of the dynamics of phytoplankton community hasn't been given in this study since the samples only cover a period of 2 months. Hence there is a need to carry out successive studies to investigate the succession of the phytoplankton community within the culture ponds sampled over several years in order to fully characterize the variations both due to water quality and variability in climatic conditions. This study is useful for the future research as a foundation study towards characterization of phytoplankton community dynamics in an IMTA system. 
Acknowledgements. We thank the manager and staff of the farm for providing experimental site, offering management data. This study was supported by the National Key Research and Development Program of China (2018YFD0900702-4), the Qingdao postdoctoral applied research project (JZ1920S10600), the National Natural Science Foundation of China (31873039), the China Agriculture Research System (No. CARS-48) and the Taishan Industrial Leader Talent Project of Shandong Province (No. LJNY 2015002).

\section{REFERENCES}

[1] Abdel-Tawwab, M. (2011): Natural food selectivity changes with weights of Nile tilapia, Oreochromis niloticus (Linnaeus), reared in fertilized earthen ponds. - Journal of Applied Aquaculture 23(1): 58-66.

[2] Acinas, S. G., Marcelino, L. A., Klepac-Ceraj, V., Polz, M. F. (2004): Divergence and redundancy of $16 \mathrm{~S}$ rRNA sequences in genomes with multiple rrn operons. - Journal of Bacteriology 186(9): 2629-2635.

[3] Ajani, P. A., Armbrecht, L. H., Kersten, O., Kohli, G. S., Murray, S. A. (2016): Diversity, temporal distribution and physiology of the centric diatom Leptocylindrus Cleve (Bacillariophyta) from a southern hemisphere upwelling system. - Diatom Research 31(4): 351-365.

[4] Ajin, A. M., Silvester, R., Alexander, D., Nashad, M., Abdulla, M. H. (2016): Characterization of blooming algae and bloom-associated changes in the water quality parameters of traditional pokkali cum prawn fields along the South West coast of India. Environmental Monitoring and Assessment 188(3): 145.

[5] Alonso-Rodriguez, R., Páez-Osuna, F. (2003): Nutrients, phytoplankton and harmful algal blooms in shrimp ponds: a review with special reference to the situation in the Gulf of California. - Aquaculture 219(1-4): 317-336.

[6] Baffone, W., Tarsi, R., Pane, L., Campana, R., Repetto, B., Mariottini, G. L., Pruzzo, C. (2006): Detection of free-living and plankton-bound vibrios in coastal waters of the Adriatic Sea (Italy) and study of their pathogenicity-associated properties. Environmental Microbiology 8(7): 1299-1305.

[7] Bormans, M., Maršálek, B., Jančula, D. (2016): Controlling internal phosphorus loading in lakes by physical methods to reduce cyanobacterial blooms: a review. - Aquatic Ecology 50(3): 407-422.

[8] Braak, C. T., Smilauer, P. (2002): Canoco Reference Manual and User's Guide to Canoco for Windows: Software for Canonical Community Ordination (Version 4.5). Microcomputer Power, New York.

[9] Bricelj, V. M., Malouf, R. E. (1984): Influence of algal and suspended sediment concentrations on the feeding physiology of the hard clam Mercenaria mercenaria. Marine Biology 84(2): 155-165.

[10] Brito, L. O., dos Santos, I. G. S., de Abreu, J. L., de Araujo, M. T., Sever, W., Galvez, A. O. (2016): Effect of the addition of diatoms (Navicula spp.) and rotifers (Brachionus plicatilis) on water quality and growth of the Litopenaeus vannamei postlarvae reared in a biofloc system. - Aquaculture Research 47(12): 3990-3997.

[11] Burford, M. A., Costanzo, S. D., Dennison, W. C., Jackson, C. J., Jones, A. B., McKinnon, A. D., Preston, N. P., Trott, L. A. (2003): A synthesis of dominant ecological processes in intensive shrimp ponds and adjacent coastal environments in NE Australia. Marine Pollution Bulletin 46(11): 1456-1469.

[12] Caporaso, J. G., Kuczynski, J., Stombaugh, J., Bittinger, K., Bushman, F. D., Costello, E. K., Fierer, N., Peña, A. G., Goodrich, J. K., Gordon, J. I., Huttley, G. A., Kelley, S. T., Knights, D., Koenig, J. E., Ley, R. E., Lozupone, C. A., McDonald, D., Muegge, B. D., Pirrung, M., Reeder, J., Sevinsky, J. R., Turnbaugh, P. J., Walters, W. A., Widmann, J., 
Yatsunenko, T., Zaneveld, J., Knight, R. (2010): QIIME allows analysis of highthroughput community sequencing data. - Nature Methods 7(5): 335-336.

[13] Chopin, T., Robinson, S. M. C., Troell, M., Neori, A., Buschmann, A. H., Fang, J. (2008): Multitrophic Integration for Sustainable Marine Aquaculture. - In: Jorgensen, S. E., Fath, B. D. (eds.) The Encyclopedia of Ecology, Ecological Engineering, pp. 2463-2475.

[14] Conforti, V. (1998): Morphological changes of Euglenophyta in response to organic enrichment. - Springer-Interscience, pp. 277-285.

[15] Dantas, D. D., Rubim, P. L., de Oliveira, F. A., Da Costa, M. R., de Moura, C. G., Teixeira, L. H., Attayde, J. L. (2019): Effects of benthivorous and planktivorous fish on phosphorus cycling, phytoplankton biomass and water transparency of a tropical shallow lake. - Hydrobiologia 829(1): 31-41.

[16] DePaola, A., Nordstrom, J. L., Bowers, J. C., Wells, J. G., Cook, D. W. (2003): Seasonal abundance of total and pathogenic Vibrio parahaemolyticus in Alabama oysters. Applied and Environmental Microbiology 69(3): 1521-1526.

[17] Downing, J. A., Watson, S. B., McCauley, E. (2001): Predicting cyanobacteria dominance in lakes. - Canadian Journal of Fisheries and Aquatic Sciences 58(10): 19051908.

[18] Edgar, R. C. (2013): UPARSE: highly accurate OTU sequences from microbial amplicon reads. - Nature Methods 10(10): 996-998.

[19] Edgar, R. C., Haas, B. J., Clemente, J. C., Quince, C., Knight, R. (2011): Uchime improves sensitivity and speed of chimera detection. - Bioinformatics 27(16): 2194.

[20] Edvardsen, B., Paasche, E. (1992): Two motile stages of Chrysochromulina polylepis (prymnesiophyceae): morphology, growth, and toxicity. - Journal of Phycology 28(1): 104-114.

[21] Eiler, A., Gonzalez-Rey, C., Allen, S., Bertilsson, S. (2007): Growth response of Vibrio cholerae and other Vibrio spp. to cyanobacterial dissolved organic matter and temperature in brackish water. - FEMS Microbiology Ecology 60(3): 411-418.

[22] Engesmo, A., Eikrem, W., Seoane, S., Smith, K., Edvardsen, B., Hofgaard, A., Tomas, C. R. (2016): New insights into the morphology and phylogeny of Heterosigma akashiwo (Raphidophyceae): with the description of Heterosigma minor sp. nov. - Phycologia 55(3): 279-294.

[23] Figueredo, C. C., Giani, A. (2005): Ecological interactions between Nile tilapia (Oreochromis niloticus, L.) and the phytoplanktonic community of the Furnas Reservoir (Brazil). - Freshwater Biology 50(8): 1391-1403.

[24] Fu, K. Z., Moe, B., Li, X., Le, X. C. (2015): Cyanobacterial bloom dynamics in Lake Taihu. - Journal of Environmental Sciences 32: 249-251.

[25] Glibert, P. M., Heil, C. A., Hollander, D. J., Revilla, M. I., Hoare, A., Alexander, J. A., Murasko, S. (2004): Evidence for dissolved organic nitrogen and phosphorus uptake during a cyanobacterial bloom in Florida Bay. - Marine Ecology Progress Series 280: 7383.

[26] González-Madina, L., Pacheco, J. P., Yema, L., de Tezanos, P., Levrini, P., Clemente, J., Crisci, C., Lagomarsino, J. J., Méndez, G., Fosalba, C. (2019): Drivers of cyanobacteria dominance, composition and nitrogen fixing behavior in a shallow lake with alternative regimes in time and space, Laguna del Sauce (Maldonado, Uruguay). - Hydrobiologia 829(1): 61-76.

[27] Harrison, W. G., Perry, T., Li, W. K. (2005): Ecosystem indicators of water quality Part I. Plankton biomass, primary production and nutrient demand. - Springer-Interscience, $\mathrm{pp}$. 59-82.

[28] Hosseini Aghuzbeni, S. H., Hajirezaee, S., Matinfar, A., Khara, H., Ghobadi, M. (2017): A preliminary study on polyculture of western white shrimp (Litopenaeus vannamei) with mullet (Mugil cephalus): an assessment of water quality, growth parameters, feed intake efficiency and survival. - Journal of Applied Animal Research 45(1): 247-251. 
[29] Huang, S., Wu, M., Zang, C., Du, S., Domagalski, J., Gajewska, M., Gao, F., Lin, C., Guo, Y., Liu, B. (2016): Dynamics of algae growth and nutrients in experimental enclosures culturing bighead carp and common carp: Phosphorus dynamics. International Journal of Sediment Research 31(2): 173-180.

[30] Huisman, J., Codd, G. A., Paerl, H. W., Ibelings, B. W., Verspagen, J. M. H., Visser, P. M. (2018): Cyanobacterial blooms. - Nature Reviews Microbiology 16(8): 471-483.

[31] Hulot, V., Saulnier, D., Lafabrie, C., Gaertner-Mazouni, N. (2018): Shrimp culture: a complex driver of planktonic communities. - Reviews in Aquaculture: 1-14.

[32] Islam, M. S., Rahim, Z., Alam, M. J., Begum, S., Moniruzzaman, S. M., Umeda, A., Amako, K., Albert, M. J., Sack, R. B., Huq, A. (1999): Association of Vibrio cholerae O1 with the cyanobacterium, Anabaena sp., elucidated by polymerase chain reaction and transmission electron microscopy. - Transactions of the Royal Society of Tropical Medicine and Hygiene 93(1): 36-40.

[33] Islam, M. S., Mahmuda, S., Morshed, M. G., Bakht, H. B., Khan, M. N., Sack, R. B., Sack, D. A. (2004): Role of cyanobacteria in the persistence of Vibrio cholerae O139 in saline microcosms. - Canadian journal of microbiology 50(2): 127-131.

[34] Jena, J. K., Ayyappan, S., Aravindakshan, P. K., Dash, B., Singh, S. K., Muduli, H. K. (2002): Evaluation of production performance in carp polyculture with different stocking densities and species combinations. - Journal of Applied Ichthyology 18(3): 165-171.

[35] Jeong, H. J., Kim, T. H., Yoo, Y. D., Yoon, E. Y., Kim, J. S., Seong, K. A., Kim, K. Y., Park, J. Y. (2011): Grazing impact of heterotrophic dinoflagellates and ciliates on common red-tide euglenophyte Eutreptiella gymnastica in Masan Bay, Korea. - Harmful Algae 10(6): 576-588.

[36] Jones, A. B., Preston, N. P., Dennison, W. C. (2002): The efficiency and condition of oysters and macroalgae used as biological filters of shrimp pond effluent. - Aquaculture Research 33(1): 1-19.

[37] Justić, D., Rabalais, N. N., Turner, R. E., Dortch, Q. (1995): Changes in nutrient structure of river-dominated coastal waters: stoichiometric nutrient balance and its consequences. Estuarine, Coastal and Shelf Science 40(3): 339-356.

[38] Kingston, M. B. (1999): Effect of light on vertical migration and photosynthesis of Euglena proxima (Euglenophyta). - Journal of Phycology 35(2): 245-253.

[39] Kingston, M. B. (2002): Effect of subsurface nutrient supplies on the vertical migration of Euglena proxima (Euglenophyta). - Journal of Phycology 38(5): 872-880.

[40] Kong, Y., Xu, X., Zhu, L., Miao, L. (2013): Control of the harmful alga Microcystis aeruginosa and absorption of nitrogen and phosphorus by Candida utilis. - Applied Biochemistry and Biotechnology 169(1): 88-99.

[41] Laza-Martínez, A., Arluzea, J., Miguel, I., Orive, E. (2012): Morphological and molecular characterization of Teleaulax gracilis $\mathrm{sp}$. nov. and T. minuta $\mathrm{sp}$. nov.(Cryptophyceae). - Phycologia 36(1): 37-52.

[42] Lee, M. J., Kim, D., Kim, Y. O., Sohn, M., Moon, C. H., Baek, S. H. (2016): Seasonal phytoplankton growth and distribution pattern by environmental factor changes in inner and outer bay of Ulsan, Korea. - The Sea 21(1): 24-35.

[43] Li, Y., Qin, J., Zheng, X., Wang, Y. (2019): Production performance of largemouth bass Micropterus salmoides and water quality variation in monoculture, polyculture and integrated culture. - Aquaculture Research 50(2): 423-430.

[44] Lio-Po, G. D., Leaño, E. M., Peñaranda, M. M. D., Villa-Franco, A. U., Sombito, C. D., Guanzon Jr, N. G. (2005): Anti-luminous Vibrio factors associated with the 'green water' grow-out culture of the tiger shrimp Penaeus monodon. - Aquaculture 250(1-2): 1-7.

[45] Liu, G. (2009): Characteristics, harm and regulation of Euchlorophyta bloom in aquaculture ponds. - China Fisheries 2: 59-60.

[46] MacDonald, B. A., Robinson, S. M. C., Barrington, K. A. (2011): Feeding activity of mussels (Mytilus edulis) held in the field at an integrated multi-trophic aquaculture 
(IMTA) site (Salmo salar) and exposed to fish food in the laboratory. - Aquaculture 314(1-4): 244-251.

[47] Magoc, T., Salzberg, S. L. (2011): Flash: fast length adjustment of short reads to improve genome assemblies. - Bioinformatics 27(21): 2957-2963.

[48] Makridis, P., Costa, R. A., Dinis, M. T. (2006): Microbial conditions and antimicrobial activity in cultures of two microalgae species, Tetraselmis chuii and Chlorella minutissima, and effect on bacterial load of enriched Artemia metanauplii. - Aquaculture 255(1-4): 76-81.

[49] Martins, T. G., Odebrecht, C., Jensen, L. V., D'Oca, M. G., Wasielesky Jr, W. (2016): The contribution of diatoms to bioflocs lipid content and the performance of juvenile Litopenaeus vannamei (Boone, 1931) in a BFT culture system. - Aquaculture Research 47(4): 1315-1326.

[50] Menezes, R. F., Attayde, J. L., Rivera Vasconcelos, F. (2010): Effects of omnivorous filter-feeding fish and nutrient enrichment on the plankton community and water transparency of a tropical reservoir. - Freshwater Biology 55(4): 767-779.

[51] Meriluoto, J., Spoof, L., Codd, G. A. (2017): Handbook of cyanobacterial monitoring and cyanotoxin analysis. - Wiley-Interscience, New York.

[52] Moisander, P. H., Steppe, T. F., Hall, N. S., Kuparinen, J., Paerl, H. W. (2003): Variability in nitrogen and phosphorus limitation for Baltic Sea phytoplankton during nitrogen-fixing cyanobacterial blooms. - Marine Ecology Progress Series 262: 81-95.

[53] Nanjappa, D., Kooistra, W. H., Zingone, A. (2013): A reappraisal of the genus Leptocylindrus (Bacillariophyta): with the addition of three species and the erection of Tenuicylindrus gen. nov. - Journal of Phycology 49(5): 917-936.

[54] Newell, R. I. E. (2004): Ecosystem influences of natural and cultivated populations of suspension-feeding bivalve molluscs: a review. - Journal of Shellfish Research 23(1): 5162.

[55] Newell, R. I. E., Tettelbach, S. T., Gobler, C. J., Kimmel, D. G. (2009): Relationships between reproduction in suspension-feeding hard clams Mercenaria mercenaria and phytoplankton community structure. - Marine Ecology Progress 387(12): 179-196.

[56] O'Halloran, C., Silver, M. W., Holman, T. R., Scholin, C. A. (2006): Heterosigma akashiwo in central California waters. - Harmful Algae 5(2): 124-132.

[57] Olli, K., Heiskanen, A., Seppälä, J. (1996): Development and fate of Eutreptiella gymnastica bloom in nutrient-enriched enclosures in the coastal Baltic Sea. - Journal of Plankton Research 18(9): 1587-1604.

[58] Paerl, H. W., Huisman, J. (2008): Blooms like it hot. - Science 320(5872): 57-58.

[59] Parsons, T. R., Maita, Y., Lalli, C. M. (1984): A manual of chemical and biological methods for seawater analysis. - Pergamon Press, Oxford.

[60] Pérez-Morales, A., Band-Schmidt, C. J., Martínez-Díaz, S. F. (2017): Mortality on zoea stage of the Pacific white shrimp Litopenaeus vannamei caused by Cochlodinium polykrikoides (Dinophyceae) and Chattonella spp. (Raphidophyceae). - Marine Biology 164(3): 57.

[61] Pruzzo, C., Huq, A., Colwell, R. R., Donelli, G. (2005a): Pathogenic Vibrio species in the marine and estuarine environment. - In: Belkin, S., Colwell, R. R. (eds.) Oceans and Health: Pathogens in the Marine Environment. Springer, Boston MA, pp. 217-252.

[62] Pruzzo, C., Gallo, G., Canesi, L. (2005b): Persistence of vibrios in marine bivalves: the role of interactions with haemolymph components. - Environmental Microbiology 7(6): 761-772.

[63] Pulz, O., Gross, W. (2004): Valuable products from biotechnology of microalgae. Applied Microbiology and Biotechnology 65(6): 635-648.

[64] Qiao, L., Chang, Z., Li, J., Chen, Z., Yang, L., Luo, Q. (2019): Phytoplankton community structure and diversity in the indoor industrial aquaculture system for Litopenaeus vannamei revealed by high-throughput sequencing and morphological identification. Aquaculture Research 50(9): 2563-2576. 
[65] Rahman, M. M., Verdegem, M. C. (2007): Multi-species fishpond and nutrients balance. - In: van der Zijpp, A. J., Verreth, J. A. J., Le Quang Tri, van Mensvoort, M. E. F., Bosma, R. H., Beveridge, M. C. M. (eds.) Fishponds in farming systems. Wageningen Academic Publishers, The-Netherlands, pp. 79-88.

[66] Reid, G. K., Liutkus, M., Bennett, A., Robinson, S. M. C., Macdonald, B., Page, F. (2010): Absorption efficiency of blue mussels (Mytilus edulis and M. trossulus) feeding on Atlantic salmon (Salmo salar) feed and fecal particulates: Implications for integrated multi-trophic aquaculture. - Aquaculture 299(1): 165-169.

[67] Rhodes, L., Burke, B. (1996): Morphology and growth characteristics of Chrysochromulina species (Haptophyceae = Prymnesiophyceae) isolated from New Zealand coastal waters. - New Zealand Journal of Marine and Freshwater Research 30(1): 91-103.

[68] Roy, S. S., Pal, R. (2015): Microalgae in Aquaculture: A Review with Special References to Nutritional Value and Fish Dietetics. - Proceedings of the Zoological Society 68(1): 18.

[69] SAC (2007): The specification for marine monitoring-Part 4: Seawater analysis. - GB 17378.4-2007 Standards Press of China -Interscience, China. (in Chinese).

[70] Sarà, G., Reid, G. K., Rinaldi, A., Palmeri, V., Troell, M., Kooijman, S. A. L. M. (2012): Growth and reproductive simulation of candidate shellfish species at fish cages in the Southern Mediterranean: Dynamic Energy Budget (DEB) modelling for integrated multitrophic aquaculture. - Aquaculture 324(5): 259-266.

[71] Sherwood, A. R., Presting, G. G. (2007): Universal primers amplify a 23S rDNA plastid marker in eukaryotic algae and cyanobacteria. - Journal of Phycology 43(3): 605-608.

[72] Sinden, A., Sinang, S. C. (2016): Cyanobacteria in aquaculture systems: linking the occurrence, abundance and toxicity with rising temperatures. - International Journal of Environmental Science and Technology 13(12): 2855-2862.

[73] Sladonja, B. (2011): Aquaculture and the Environment: A Shared Destiny. - InTechInterscience, Croacia.

[74] Smith, J. L., Boyer, G. L., Zimba, P. V. (2008): A review of cyanobacterial odorous and bioactive metabolites: impacts and management alternatives in aquaculture. Aquaculture 280(1-4): 5-20.

[75] Stonik, I. V. (2007): Species of the genus Eutreptiella (Euglenophyceae) from Russian waters of East/Japan Sea. - Ocean Science Journal 42(2): 81-88.

[76] Stonik, I. V., Selina, M. S. (2001): Species composition and seasonal dynamics of density and biomass of euglenoids in Peter the Great Bay, Sea of Japan. - Russian Journal of Marine Biology 27(3): 174-176.

[77] Sun, W., Dong, S., Jie, Z., Zhao, X., Zhang, H., Li, J. (2011): The impact of net-isolated polyculture of tilapia (Oreochromis niloticus) on plankton community in saline-alkaline pond of shrimp (Penaeus vannamei). - Aquaculture International 19(4): 779-788.

[78] Tamplin, M. L., Gauzens, A. L., Huq, A., Sack, D. A., Colwell, R. R. (1990): Attachment of Vibrio cholerae serogroup $\mathrm{O} 1$ to zooplankton and phytoplankton of Bangladesh waters. - Applied and Environmental Microbiology 56(6): 1977-1980.

[79] Thompson, J. R., Randa, M. A., Marcelino, L. A., Tomita-Mitchell, A., Lim, E., Polz, M. F. (2004): Diversity and dynamics of a North Atlantic coastal Vibrio community. Applied and Environmental Microbiology 70(7): 4103-4110.

[80] Tian, X., Li, D., Dong, S., Yan, X., Qi, Z., Liu, G., Lu, J. (2001): An experimental study on closed-polyculture of penaeid shrimp with tilapia and constricted tagelus. Aquaculture 202(1-2): 57-71.

[81] Troell, M., Joyce, A., Chopin, T., Neori, A., Buschmann, A. H., Fang, J. (2009): Ecological engineering in aquaculture-potential for integrated multi-trophic aquaculture (IMTA) in marine offshore systems. - Aquaculture 297(1-4): 1-9. 
[82] Turner, J. W., Good, B., Cole, D., Lipp, E. K. (2009): Plankton composition and environmental factors contribute to Vibrio seasonality. - The ISME journal 3(9): 10821092.

[83] Tyrrell, J. V., Bergquist, P. R., Bergquist, P. L., Scholin, C. A. (2001): Detection and enumeration of Heterosigma akashiwo and Fibrocapsa japonica (Raphidophyceae) using rRNA-targeted oligonucleotide probes. - Phycologia 40(5): 457-467.

[84] Vasconcelos, F. R., Menezes, R. F., Attayde, J. L. (2018): Effects of the Nile tilapia (Oreochromis niloticus L.) on the plankton community of a tropical reservoir during and after an algal bloom. - Hydrobiologia: 1-9.

[85] Vezzulli, L., Brettar, I., Pezzati, E., Reid, P. C., Colwell, R. R., Höfle, M. G., Pruzzo, C. (2012): Long-term effects of ocean warming on the prokaryotic community: evidence from the vibrios. - The ISME journal 6(1): 21-30.

[86] Wang, J., Li, D., Dong, S., Wang, K., Tian, X. (1999): Comparative studies on cultural efficiency and profits of different polycultural systems in penaeid shrimp ponds. - Journal of Fisheries of China 23(1): 45-52. (in Chinese).

[87] Wartenberg, R., Feng, L., Wu, J. J., Mak, Y. L., Chan, L. L., Telfer, T. C., Lam, P. K. (2017): The impacts of suspended mariculture on coastal zones in China and the scope for Integrated Multi-Trophic Aquaculture. - Ecosystem Health and Sustainability 3(6): 1340268.

[88] Wright, A. C., Hill, R. T., Johnson, J. A., Roghman, M., Colwell, R. R., Morris, J. G. (1996): Distribution of Vibrio vulnificus in the Chesapeake Bay. - Applied and Environmental Microbiology 62(2): 717-724.

[89] Wu, T., Qin, B., Zhu, G., Luo, L., Ding, Y., Bian, G. (2013): Dynamics of cyanobacterial bloom formation during short-term hydrodynamic fluctuation in a large shallow, eutrophic, and wind-exposed Lake Taihu, China. - Environmental Science and Pollution Research 20(12): 8546-8556.

[90] Xing, X., Chen, C., Gao, Y., Liang, J., Huang, H., Li, B., Ho, K., Lin, X., Qi, Y. (2008): Observations of several cryptomonad flagellates from China Sea by scanning electron microscopy. - Journal of Systematics and Evolution 46(2): 205-212.

[91] Xu, F., Hu, L., Zhou, Z., Zhong, N., Wu, S., Cai, T., Peng, L., Zhu, S. (2015): The algae on the impact of change on aquaculture research progress. - Journal of Aquaculture 36(1): 48-52. (in Chinese).

[92] Yoo, Y. D., Seong, K. A., Kim, H. S., Jeong, H. J., Yoon, E. Y., Park, J., Kim, J. I., Shin, W., Palenik, B. (2018): Feeding and grazing impact by the bloom-forming euglenophyte Eutreptiella eupharyngea on marine eubacteria and cyanobacteria. - Harmful Algae 73: 98-109.

[93] Zhu, A. J., Huang, L. M., Lin, Q. Y., Zhan-Zhou, X. U. (2009): Influence of nitrogen and phosphorus on phytoplankton community structure in the Dapeng'ao Bay, Daya Bay: II Species composition. - Journal of Tropical Oceanography 28(6): 103-111. (in Chinese).

[94] Zhuang, S. H., Wang, Z. Q. (2004): Influence of size, habitat and food concentration on the feeding ecology of the bivalve, Meretrix meretrix Linnaeus. - Aquaculture 241(1-4): 689-699.

[95] Zimba, P. V., Huang, I., Gutierrez, D., Shin, W., Bennett, M. S., Triemer, R. E. (2017): Euglenophycin is produced in at least six species of euglenoid algae and six of seven strains of Euglena sanguinea. - Harmful Algae 63: 79-84. 


\section{APPENDICES}

Table A.1. List of phytoplankton species from integrated multi-trophic aquaculture system revealed by morphological analysis

\begin{tabular}{|c|c|c|c|c|c|c|c|c|c|}
\hline \multirow{2}{*}{ Phylum } & \multirow{2}{*}{ Species } & \multicolumn{4}{|c|}{ September } & \multicolumn{4}{|c|}{ October } \\
\hline & & \begin{tabular}{|l|} 
Pond 1 \\
\end{tabular} & Pond 3 & Pond 5 & Pond 6 & Pond 1 & Pond 3 & Pond 5 & Pond 6 \\
\hline Bacillariophyta & $\begin{array}{c}\text { Cerataulina pelagica (Cleve) } \\
\text { Hendey } \\
\text { Chaetoceros sp. } \\
\text { Cyclotella meneghiniana } \\
\text { Kuetzing } \\
\text { Cyclotella } \text { sp. } \\
\text { Cyclotella striata (Kütz.) } \\
\text { Grunow in Cleve \& Grunow } \\
\text { Cylindrotheca closterium (Ehr) } \\
\text { Reimann et Lewin } \\
\text { Dactyliosolen fragilissimus } \\
\text { (Bergon) Hasle, } 1996 \\
\text { Melosira } \text { sp. } \\
\text { Navicula } \text { sp. } \\
\text { Nitzschia } \text { sp.1 } \\
\text { Nitzschia } \text { sp.2 } \\
\text { Nitzschia panduriformis } \\
\text { Pinnularia } \text { sp. } \\
\text { Pleurosigma } \text { sp. } \\
\text { Skeletonema costatum (Greville) } \\
\text { Cleve emend. Zingone et Sarno } \\
\text { Surirella } \text { sp. } \\
\text { Amphora sp. } \\
\text { Amphiprora alata(Ehrenebrg) } \\
\text { Kuetzings } \\
\text { Leptocylindrus danicus } \\
\text { Pleurosigma acutum } \\
\text { Achnanthes brevipes } \\
\text { Melosira sulcata } \\
\end{array}$ & $\begin{array}{l}\sqrt{ } \\
\sqrt{ } \\
\sqrt{ } \\
\sqrt{ } \\
\sqrt{ } \\
\sqrt{ } \\
\sqrt{ } \\
\sqrt{ } \\
\sqrt{ } \\
\sqrt{ } \\
\sqrt{ } \\
\sqrt{ }\end{array}$ & $\begin{array}{l}\sqrt{ } \\
\sqrt{ } \\
\sqrt{ } \\
\sqrt{ } \\
\sqrt{ } \\
\sqrt{ } \\
\sqrt{ } \\
\sqrt{ } \\
\sqrt{ }\end{array}$ & $\begin{array}{l}\sqrt{ } \\
\sqrt{ } \\
\sqrt{ } \\
\sqrt{ } \\
\sqrt{ } \\
\sqrt{ }\end{array}$ & $\begin{array}{l}\sqrt{ } \\
\sqrt{ } \\
\sqrt{ } \\
\sqrt{ } \\
\sqrt{ }\end{array}$ & $\begin{array}{l}\sqrt{ } \\
\sqrt{ } \\
\sqrt{ }\end{array}$ & $\begin{array}{l}\sqrt{ } \\
\sqrt{ } \\
\sqrt{ } \\
\sqrt{ } \\
\sqrt{ }\end{array}$ & $\begin{array}{l}\sqrt{ } \\
\sqrt{ } \\
\sqrt{ } \\
\sqrt{ }\end{array}$ & $\begin{array}{l}\sqrt{ } \\
\sqrt{ } \\
\sqrt{ }\end{array}$ \\
\hline Dinophyta & \begin{tabular}{|c|} 
Gymnodinium spp. \\
Gymnodinium simplex \\
(Lohmann) Kofoid \& Swezy \\
Gonyaulax verior Sournai \\
Gyrodinium spirale (Bergh) \\
Kofoid et Swezy \\
Prorocentrum micans Ehrenberg \\
Protoperidinium pellucidum \\
Protoperidinium sp. \\
Azadinium sp. \\
Scrippsiella trochoidea \\
\end{tabular} & $\sqrt{ }$ & $\begin{array}{l}\sqrt{ } \\
\sqrt{ }\end{array}$ & $\begin{array}{l}\sqrt{ } \\
\sqrt{ }\end{array}$ & $\sqrt{ }$ & $\begin{array}{l}\sqrt{ } \\
\sqrt{ } \\
\sqrt{ } \\
\sqrt{ } \\
\sqrt{ } \\
\sqrt{ } \\
\sqrt{ }\end{array}$ & $\begin{array}{l}\sqrt{ } \\
\sqrt{ } \\
\sqrt{ } \\
\sqrt{ } \\
\sqrt{ } \\
\sqrt{ } \\
\sqrt{ }\end{array}$ & $\begin{array}{l}\sqrt{ } \\
\sqrt{ } \\
\sqrt{ } \\
\sqrt{ }\end{array}$ & $\begin{array}{l}\sqrt{ } \\
\sqrt{ }\end{array}$ \\
\hline Cryptophyta & $\begin{array}{c}\text { Chroomonas acuta Uterm } \\
\text { Teleaulax acuta } \\
\text { Cryptomonas } \mathrm{sp} . \\
\text { Rhodomonas } \mathrm{sp} . \\
\text { Teleaulax } \mathrm{sp} . \\
\end{array}$ & $\sqrt{ }$ & $\sqrt{ }$ & $\begin{array}{l}\sqrt{ } \\
\sqrt{ } \\
\sqrt{ }\end{array}$ & $\sqrt{ }$ & $\sqrt{ }$ & $\sqrt{ }$ & $\begin{array}{l}\sqrt{ } \\
\sqrt{ } \\
\sqrt{ }\end{array}$ & $\begin{array}{l}\text { V } \\
\sqrt{ } \\
\sqrt{ } \\
\sqrt{ }\end{array}$ \\
\hline Chlorophyta & $\begin{array}{l}\text { Dunaliella salina (Dunal) } \\
\text { Teodoresco, } 1905 \\
\text { Pyramimonas } \mathrm{sp} . \\
\text { Nephroselmis pyriformis } \\
\text { (N.Carter) Ettl } \\
\text { Scenedesmus } \mathrm{sp} \text {. }\end{array}$ & & $\begin{array}{l}\sqrt{ } \\
\sqrt{ }\end{array}$ & $\begin{array}{l}\sqrt{ } \\
\sqrt{ }\end{array}$ & $\sqrt{ }$ & $\sqrt{ }$ & $\sqrt{ }$ & $\sqrt{ }$ & $\begin{array}{l}\sqrt{ } \\
\sqrt{ }\end{array}$ \\
\hline Cyanophyta & $\begin{array}{c}\text { Oscillatoria } \mathrm{sp} . \\
\text { Chroococcus turgidus } \\
\text { Mastigocoleus } \mathrm{sp} .\end{array}$ & $\sqrt{ }$ & $\sqrt{ }$ & $\sqrt{ }$ & $\begin{array}{l}\sqrt{ } \\
\sqrt{ }\end{array}$ & & & & \\
\hline Euglenophyta & Eutreptiella sp. & & $\sqrt{ }$ & $\sqrt{ }$ & $\sqrt{ }$ & $\sqrt{ }$ & $\sqrt{ }$ & $\sqrt{ }$ & $\sqrt{ }$ \\
\hline
\end{tabular}




$$
-3932-
$$

Table A.2. List of phytoplankton species from integrated multi-trophic aquaculture system revealed by high-throughput sequencing

\begin{tabular}{|c|c|c|c|c|c|c|c|c|c|}
\hline \multirow{2}{*}{ Phylum } & \multirow{2}{*}{ Species } & \multicolumn{4}{|c|}{ September } & \multicolumn{4}{|c|}{ October } \\
\hline & & Pond 1 & Pond 3 & Pond 5 & Pond 6 & Pond 1 & Pond 3 & Pond 5 & Pond 6 \\
\hline \multirow[t]{21}{*}{ Cyanophyta } & OTU1 & $\sqrt{ }$ & $\sqrt{ }$ & $\sqrt{ }$ & & $\sqrt{ }$ & $\sqrt{ }$ & & \\
\hline & OTU2 & $\sqrt{ }$ & $\sqrt{ }$ & $\sqrt{ }$ & $\sqrt{ }$ & $\sqrt{ }$ & $\sqrt{ }$ & & \\
\hline & OTU4 & $\sqrt{ }$ & $\sqrt{ }$ & & $\sqrt{ }$ & & $\sqrt{ }$ & & \\
\hline & OTU5 & $\sqrt{ }$ & $\sqrt{ }$ & $\sqrt{ }$ & $\sqrt{ }$ & $\sqrt{ }$ & $\sqrt{ }$ & & $\sqrt{ }$ \\
\hline & OTU6 & $\sqrt{ }$ & $\sqrt{ }$ & $\sqrt{ }$ & $\sqrt{ }$ & $\sqrt{ }$ & $\sqrt{ }$ & $\sqrt{ }$ & $\sqrt{ }$ \\
\hline & OTU13 & $\sqrt{ }$ & $\sqrt{ }$ & $\sqrt{ }$ & & & $\sqrt{ }$ & & \\
\hline & OTU20 & & & & & & & & \\
\hline & OTU21 & $\sqrt{ }$ & & & & $\sqrt{ }$ & $\sqrt{ }$ & & \\
\hline & OTU23 & & & & $\sqrt{ }$ & & & & $\sqrt{ }$ \\
\hline & OTU35 & & & & $\sqrt{ }$ & & & & \\
\hline & OTU61 & $\sqrt{ }$ & $\sqrt{ }$ & $\sqrt{ }$ & & $\sqrt{ }$ & $\sqrt{ }$ & & \\
\hline & OTU63 & $\sqrt{ }$ & $\sqrt{ }$ & $\sqrt{ }$ & & $\sqrt{ }$ & $\sqrt{ }$ & & \\
\hline & OTU64 & & & & $\sqrt{ }$ & $\sqrt{ }$ & $\sqrt{ }$ & & \\
\hline & OTU72 & & $\sqrt{ }$ & & & $\sqrt{ }$ & $\sqrt{ }$ & & \\
\hline & OTU73 & & $\sqrt{ }$ & & & $\sqrt{ }$ & & & \\
\hline & OTU84 & $\sqrt{ }$ & $\sqrt{ }$ & $\sqrt{ }$ & $\sqrt{ }$ & $\sqrt{ }$ & $\sqrt{ }$ & & \\
\hline & OTU93 & $\sqrt{ }$ & $\sqrt{ }$ & $\sqrt{ }$ & $\sqrt{ }$ & $\sqrt{ }$ & $\sqrt{ }$ & & \\
\hline & OTU94 & $\sqrt{ }$ & $\sqrt{ }$ & $\sqrt{ }$ & & $\sqrt{ }$ & $\sqrt{ }$ & $\sqrt{ }$ & $\sqrt{ }$ \\
\hline & OTU95 & $\sqrt{ }$ & $\sqrt{ }$ & $\sqrt{ }$ & $\sqrt{ }$ & $\sqrt{ }$ & $\sqrt{ }$ & & \\
\hline & OTU97 & $\sqrt{ }$ & $\sqrt{ }$ & $\sqrt{ }$ & $\sqrt{ }$ & $\sqrt{ }$ & $\sqrt{ }$ & & \\
\hline & OTU106 & $\sqrt{ }$ & $\sqrt{ }$ & $\sqrt{ }$ & & $\sqrt{ }$ & $\sqrt{ }$ & $\sqrt{ }$ & \\
\hline \multirow[t]{19}{*}{ Chlorophyta } & OTU3 & $\sqrt{1}$ & $\sqrt{ }$ & & $\sqrt{1}$ & & & & \\
\hline & OTU19 & $\sqrt{ }$ & $\sqrt{ }$ & $\sqrt{ }$ & $\sqrt{ }$ & & & $\sqrt{ }$ & $\sqrt{ }$ \\
\hline & OTU32 & & & $\sqrt{ }$ & & & & $\sqrt{ }$ & $\sqrt{ }$ \\
\hline & OTU42 & & & & & & & $\sqrt{ }$ & \\
\hline & OTU44 & & $\sqrt{ }$ & $\sqrt{ }$ & $\sqrt{ }$ & & & $\sqrt{ }$ & \\
\hline & OTU50 & & & & & & & & \\
\hline & OTU74 & $\sqrt{ }$ & $\sqrt{ }$ & & & & $\sqrt{ }$ & $\sqrt{ }$ & \\
\hline & OTU88 & $\sqrt{ }$ & $\sqrt{ }$ & & & $\sqrt{ }$ & $\sqrt{ }$ & $\sqrt{ }$ & $\sqrt{ }$ \\
\hline & OTU99 & & & & & $\sqrt{ }$ & $\sqrt{ }$ & & \\
\hline & OTU110 & & & & & & & $\sqrt{ }$ & $\sqrt{ }$ \\
\hline & OTU116 & & & & $\sqrt{ }$ & & & $\sqrt{ }$ & $\sqrt{ }$ \\
\hline & OTU121 & & & $\sqrt{ }$ & & & & $\sqrt{ }$ & $\sqrt{ }$ \\
\hline & OTU122 & & & & & & & $\sqrt{ }$ & \\
\hline & OTU123 & $\sqrt{ }$ & $\sqrt{ }$ & & & $\sqrt{ }$ & $\sqrt{ }$ & $\sqrt{ }$ & $\sqrt{ }$ \\
\hline & $\begin{array}{l}\text { OTU127 } \\
\text { OTU136 }\end{array}$ & & & & $\sqrt{ }$ & & & $\sqrt{ }$ & $\sqrt{ }$ \\
\hline & OTU145 & & & & & $\sqrt{ }$ & & & $\sqrt{ }$ \\
\hline & OTU154 & & & & & $\sqrt{ }$ & $\sqrt{ }$ & $\sqrt{ }$ & $\sqrt{ }$ \\
\hline & OTU155 & & & $\sqrt{ }$ & & 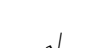 & & & $\sqrt{ }$ \\
\hline & OTU157 & & & & & $\sqrt{ }$ & & $\sqrt{ }$ & $\sqrt{ }$ \\
\hline \multirow[t]{11}{*}{ Bacillariophyta } & OTU10 & & & $\sqrt{ }$ & $\sqrt{ }$ & & & $\sqrt{ }$ & \\
\hline & OTU14 & & & $\sqrt{ }$ & $\sqrt{ }$ & & & & \\
\hline & OTU26 & & & & $\sqrt{ }$ & & & & \\
\hline & OTU79 & & & & & $\sqrt{ }$ & $\sqrt{ }$ & & \\
\hline & OTU96 & $\sqrt{ }$ & & $\sqrt{ }$ & & $\sqrt{ }$ & $\sqrt{ }$ & & \\
\hline & OTU105 & $\sqrt{ }$ & & & & $\sqrt{ }$ & $\sqrt{ }$ & $\sqrt{ }$ & $\sqrt{ }$ \\
\hline & OTU109 & $\sqrt{ }$ & $\sqrt{ }$ & $\sqrt{ }$ & & $\sqrt{ }$ & $\sqrt{ }$ & & \\
\hline & OTU128 & & & $\sqrt{ }$ & & & & & \\
\hline & OTU135 & & & & & & & & $\sqrt{ }$ \\
\hline & OTU146 & & & $\sqrt{ }$ & & $\sqrt{ }$ & $\sqrt{ }$ & $\sqrt{ }$ & $\sqrt{ }$ \\
\hline & OTU148 & $\sqrt{ }$ & $\sqrt{ }$ & $\sqrt{ }$ & & $\sqrt{ }$ & $\sqrt{ }$ & $\sqrt{ }$ & $\sqrt{ }$ \\
\hline \multirow[t]{4}{*}{ Dinophyta } & OTU69 & & & $\sqrt{ }$ & & $\sqrt{ }$ & $\sqrt{1}$ & $\sqrt{ }$ & $\sqrt{ }$ \\
\hline & OTU71 & & & & & $\sqrt{ }$ & $\sqrt{ }$ & & \\
\hline & OTU152 & & & & & & & & $\sqrt{ }$ \\
\hline & OTU162 & & & & & & & & $\sqrt{ }$ \\
\hline \multirow[t]{3}{*}{ Cryptophyta } & OTU111 & & $\sqrt{ }$ & $\sqrt{ }$ & & $\sqrt{ }$ & $\sqrt{ }$ & $\sqrt{ }$ & $\sqrt{ }$ \\
\hline & OTU117 & & & $\sqrt{ }$ & & $\sqrt{ }$ & $\sqrt{ }$ & $\sqrt{ }$ & $\sqrt{ }$ \\
\hline & OTU119 & & & $\sqrt{ }$ & $\sqrt{ }$ & $\sqrt{ }$ & $\sqrt{ }$ & $\sqrt{ }$ & $\sqrt{ }$ \\
\hline
\end{tabular}


Qiao et al.: Phytoplankton community structure in an integrated multi-trophic aquaculture system revealed by morphological analysis and high-throughput sequencing

$$
-3933-
$$

\begin{tabular}{|c|c|c|c|c|c|c|c|c|c|}
\hline \multirow{2}{*}{ Phylum } & \multirow{2}{*}{ Species } & \multicolumn{4}{|c|}{ September } & \multicolumn{4}{|c|}{ October } \\
\hline & & Pond 1 & Pond 3 & Pond 5 & Pond 6 & Pond 1 & Pond 3 & Pond 5 & Pond 6 \\
\hline Ochrophyta & $\begin{array}{c}\text { OTU78 } \\
\text { OTU107 } \\
\text { OTU108 }\end{array}$ & $\sqrt{ }$ & $\sqrt{ }$ & $\sqrt{ }$ & $\sqrt{ }$ & $\begin{array}{l}\sqrt{ } \\
\sqrt{ } \\
\sqrt{ }\end{array}$ & $\begin{array}{l}\sqrt{ } \\
\sqrt{ } \\
\sqrt{ }\end{array}$ & $\sqrt{ }$ & $\sqrt{ }$ \\
\hline Haptophyta & $\begin{array}{c}\text { OTU75 } \\
\text { OTU103 } \\
\text { OTU114 }\end{array}$ & $\sqrt{ }$ & $\sqrt{ }$ & & $\sqrt{ }$ & $\begin{array}{l}\sqrt{1} \\
\sqrt{ } \\
\sqrt{ }\end{array}$ & $\begin{array}{l}\sqrt{ } \\
\sqrt{ } \\
\sqrt{ }\end{array}$ & $\begin{array}{l}\sqrt{1} \\
\sqrt{ } \\
\sqrt{ }\end{array}$ & $\sqrt{ }$ \\
\hline Euglenophyta & $\begin{array}{c}\text { OTU43 } \\
\text { OTU124 }\end{array}$ & & & $\sqrt{ }$ & $\sqrt{ }$ & $\sqrt{ }$ & $\sqrt{ }$ & $\sqrt{ }$ & $\sqrt{ }$ \\
\hline Raphidophyta & OTU137 & & $\sqrt{ }$ & & $\sqrt{ }$ & & & & $\sqrt{ }$ \\
\hline
\end{tabular}

